\title{
Conventional PCR primers for the detection of grapevine pathogens disseminated by propagating material
}

\author{
Manduláné Farkasi', E., Czotter², N., Lózsa³, R., Dula ${ }^{4}$, T., Ember³, I., \\ Várallyay $^{2}$, É. \& Szegedi ${ }^{1 \#}$, E. \\ ${ }^{I}$ National Agricultural Research and Innovation Centre, Research Institute for Viticulture and Enology, \\ Experimental Station of Kecskemét, 6000 Kecskemét-Katonatelep, Katona Zsigmond út 5., Hungary \\ ${ }^{2}$ National Agricultural Research and Innovation Centre, Agricultural Biotechnology Institute, 2100 Gödöllö, \\ Szent-Györgyi Albert út 4., Hungary \\ ${ }^{3}$ Corvinus University of Budapest, Faculty of Horticulture, Department of Viticulture, \\ 1118 Budapest, Villányi út 29-43., Hungary \\ ${ }^{4}$ DULA Grape \& Wine Advisory Ltd., 3300 Eger, Eszterházy tér 9., Hungary; szegedi.erno@naik.hu
}

\begin{abstract}
Summary: Polymerase chain reaction driven by sequence specific primers has become the most widely used diagnostic method to detect and identify plant pathogens. The sensitive and cost-effective pathogen detection is exceptionally important in the production of propagating material. In this paper we have collected primer sequence data from the literature for the detection of the most important grapevine pathogens disseminated by propagating stocks by conventional polymerase chain reaction. Basic protocols to obtain template nucleic acids have also been briefly rewieved.
\end{abstract}

Keywords:bacteria, fungi, phytoplasmas, polymerase chain reaction, primer sequences, viroids, viruses, Vitis vinifera

Grapevine cultivation is endangered by several pathogens disseminated in latent form by propagating material. These pathogens include several viroids, viruses, phytoplasmas, bacteria and fungi (Bisztray et al. 2012, Martelli 2014). Their presence in the plant frequently cannot be recognized by symptoms in the plantations, but disease outbreak may take place in the later stage of infection or in the new plantations under favourable environmental conditions. Therefore the use of healthy planting material has a vital importance. Pathogen-free grapevine stocks can be selected from the existing plantations by various diagnostic protocols or produced by various curative (e. g., hot water) treatments and in vitro shoot tip and/or apical meristem cultures (Bisztray et al. 2012). The pathogen-free status of hot water treated and micropropagated plants should also be tested by appropriate diagnostic methods.

During the recent decades the polymerase chain reaction (PCR) has become the most common diagnostic protocol in plant pathology. The introduction of the conventional PCR (including multiplex, nested and reverse trascription PCR) has opened wide application possibilities due to its simplicity and cost effectiveness. Later, it was followed by the more sensitive, but also more costly, quantitative realtime PCR (qRT-PCR). Quantitative real-time PCR protocols have already been developed for several viroids (Papayiannis 2014, Sun et al. 2014), viruses (Harper et al. 2011, Osman \& Rowhani 2008, Pacificio et al. 2011), phytoplasmas (Angelini
2010, Fahrentrapp et al. 2013, Pelletier et al. 2009), bacteria (Dreo et al. 2007, Harper et al. 2010, Johnson et al. 2013) and fungi (Martin et al. 2012, Schena et al. 2004).

These protocols are based on the amplification of given nucleic acid sequences derived from plants or isolated microbes. Since viroids, viruses and phytoplasmas are closely associated with plant cells they are detected from total plant nucleic acid (RNA or DNA) preparations. Bacteria and fungi can be recovered from grapevine bleeding sap or from plant tissues on appropriate culture media thus they can be detected and identified both from total plant DNA and pure cultures. Recently, a medium for recovery of axenic phytoplasma cultures has also been developed (Contaldo et al. 2012) that will allow the identification of phytoplasmas from isolated colonies as well in the future.

For nucleic acid (RNA or DNA) isolation several protocols have been developed during the last decades. For rapid field sampling the use of FTA cards (Whatman) can be proposed that allows a simple collection, transport and storage of nucleic acids derived from tissue sap or from homogenized tissues. Such samples then can be processed in PCR (Grund et al. 2010) to detect plant pathogens. Kits specifically developed for plant nucleic acids isolation (e. g., Spectrum ${ }^{\mathrm{TM}}$ Plant Total RNA Kit produced by SigmaAldrich and RNeasy Plant RNA Mini Kit produced by Qiagen) are also widely used for diagnostic purposes (Cseh 2012, Gambino \& Gribaudo 2006, Li et al. 2011, Nassuth et 
al. 2000, Ragozzino et al. 2004). Conventional nucleic acid isolation protocols include the use of SDS/phenol extraction (Franke et al. 1995, Ragozzino et al. 2004), CTAB (Gambino et al. 2008, Li et al. 2008, Lodhi et al. 1994, Steenkamp et al. 1994, Zhang et al. 2012), guanidine isothiocyanate (Gambino et al. 2006, MacKenzie 1997, Vasanthaiah et al. 2008), and silica-based methods (Digiaro 2007, Gambino 2006, Hajizadeh et al 2012, Sun et al. 2014). These protocols are also suitable to isolate nucleic acids from bacteria or fungi ( Aroca \& Raposo 2007, Botha et al. 2001, Hamelin et al. 1996, Neuhauser et al. 2009, Rodrigues et al. 2003, Szegedi 2003). For PCR analysis of pure bacterial cultures a simple triton/sodium-azide lysis (Abolmaaty et al. 2002) was found highly appropriate (Szegedi \& Bottka 2002). Specific nucleic acid sequences can be enriched by magnetic capture hybridization for subsequent PCR analysis (Johnson et al. 2013).

Primer sequence data for a given pathogen group have already been published by several authors (e. g., Angelini 2010, Constable et al. 2010, Ghignone \& Migheli 2005, see also: http://www.sppadbase.ipp.cnr.it, OEEP/EPPO 2005, Palacio-Bielsa et al. 2009, Thompson et al. 2014). In the recent paper we collected a dataset of primers for conventional PCR (and reverse-transcription PCR for viroids and viruses) from the literature for the detection of various grapevine pathogens which have or may have significant importance in the production of propagating stocks. These groups of pathogens include viroids (Table 1.), the most common viruses including the newly descibed ones that may have potential importance in the future (Table 2.), phytoplasmas (Table 3.), bacteria (Table 4.) and fungi causing wooden infection frequently followed by trunk death (Table 5.). For the direct practical use of data described in this paper we list the primer sequences and the gene they are specific for, their published annealing temperatures and the length of the amplified fragments. The aim of our work is to provide comprehensive data for grapevine research and quarantine laboratories that work in studying or controlling grapevine pathogens and the plant health status of the propagation material stocks.

Table 1. Viroid-specific primers

\begin{tabular}{|c|c|c|c|c|c|}
\hline Viroid & Primer & Primer sequence (5'-3') & $\begin{array}{c}\mathbf{A t} / \mathbf{T m} \\
\left({ }^{\circ} \mathbf{C}\right)^{*}\end{array}$ & \begin{tabular}{l|} 
Fragment \\
length (nt)
\end{tabular} & Reference \\
\hline AGVd & $\begin{array}{l}\mathrm{c} 2- \\
\mathrm{h} 2+\end{array}$ & $\begin{array}{l}\text { TTCGGTGAGTACCACAGGAAC } \\
\text { ACTCGTCCCAGCGGTCCCAAC }\end{array}$ & 55 & 130 & $\begin{array}{l}\text { Wan Chow } \\
\text { Wah \& } \\
\text { Symons, } \\
1997\end{array}$ \\
\hline AGVd & $\begin{array}{l}\text { Fw } \\
\text { Rev }\end{array}$ & $\begin{array}{l}\text { GTCGACGAAGGGTCCTCAGCAGAGCACC } \\
\text { GTCGACGACGAGTCGCCAGGTGAGTCTT }\end{array}$ & 60 & 369 & $\begin{array}{l}\text { Eiras et al. } \\
2006\end{array}$ \\
\hline AGVd & \begin{tabular}{|l|} 
AGVd-P7 \\
AGVd-P8 \\
\end{tabular} & $\begin{array}{l}\text { ACCTGCAGGGAAGCTAGCTGGGTC } \\
\text { CCCTGCAGGTTTCGCCAGCAAGCGC }\end{array}$ & 56 & 369 & $\begin{array}{l}\text { Jiang et al. } \\
2009 \mathrm{~b}\end{array}$ \\
\hline AGVd & $\begin{array}{l}\text { AGVd-mF } \\
\text { AGVd-mR }\end{array}$ & $\begin{array}{l}\text { GTCCTCAGGAGAGCACCGG } \\
\text { GAAAACTGGTTGGGACCGCTG } \\
\end{array}$ & 60 & 195 & $\begin{array}{l}\text { Hajizadeh } \\
\text { et al. } 2012\end{array}$ \\
\hline CEVd & $\begin{array}{l}\text { CEVd-Fw } \\
\text { CEVd-Rev }\end{array}$ & $\begin{array}{l}\text { GGAAACCTGGAGGAAGTCG } \\
\text { CCGGGGATCCCTGAAGGA }\end{array}$ & 60 & 375 (fl) & $\begin{array}{l}\text { Eiras et al. } \\
2006\end{array}$ \\
\hline CEVd & $\begin{array}{l}\text { CEVd-mF } \\
\text { CEVd-mR }\end{array}$ & $\begin{array}{l}\text { GTGTCCTTCCTTTGGCTGCTG } \\
\text { TGGCCCGGAGAACAGTGAAG }\end{array}$ & 51 & 153 & $\begin{array}{l}\text { Hajizadeh } \\
\text { et al. } 2012\end{array}$ \\
\hline GHVd & F1/R1 & $\begin{array}{l}\text { TTACGGAATTCTACCCCCTCCCCAGCAGATGAGATCTTTAAGTTTCGTCC } \\
\text { TTTTGGACTCGTCAGGAGCACCACA }\end{array}$ & nd & 377 & $\begin{array}{l}\text { Wu et al. } \\
2012\end{array}$ \\
\hline GHVd & $\mathrm{F} 2 / \mathrm{R} 2$ & $\begin{array}{l}\text { CACGAAGTTTAACCTTCGTAAGTCGGGCACTGTGTGGTG } \\
\text { ACTTCGTGGGAAAAGGTTACCGGCTAAGGCTTGGACCGG }\end{array}$ & nd & 382 & $\begin{array}{l}\text { Wu et al. } \\
2012\end{array}$ \\
\hline GHVd & F3/R3 & $\begin{array}{l}\text { CTCTGGCAGATTCGCTCCTAGGCTAGAACCGGTCCA } \\
\text { CAGAGCTCCAACCTCAAGAATGGCAGCTAACCTTCCCC }\end{array}$ & nd & 379 & $\begin{array}{l}\text { Wu et al. } \\
2012\end{array}$ \\
\hline GYSVd-1 & $\begin{array}{l}\text { GV1M } \\
\text { GV2P }\end{array}$ & $\begin{array}{l}\text { GCGGGGGTTCCGGGGATTGC } \\
\text { TAAGAGGTCTCCGGATCTTCTTGC }\end{array}$ & 66 & $\begin{array}{l}365-370 \\
\quad \text { (fl) }\end{array}$ & $\begin{array}{l}\text { Polivka et } \\
\text { al. } 1996\end{array}$ \\
\hline GYSVd-1 & $\begin{array}{l}\text { PBCVd100C } \\
\text { PBCVd194H }\end{array}$ & $\begin{array}{l}\text { AGACCCTTCGTCGACGACGA } \\
\text { TGTCCCGCTAGTCGAGCGGA }\end{array}$ & 56 & 220 & $\begin{array}{l}\text { Nakaune } \\
\& \text { Nakano } \\
2006 \\
\end{array}$ \\
\hline GYSVd-1 & $\begin{array}{l}\text { Fw } \\
\text { Rev }\end{array}$ & $\begin{array}{l}\text { GAGGTCCTCGGATCAC } \\
\text { AGAGCGCAATGCTGAATAGGC } \\
\end{array}$ & 60 & 222 & $\begin{array}{l}\text { Eiras et al. } \\
2006\end{array}$ \\
\hline GYSVd-1 & $\begin{array}{l}\text { GYSVd-PF } \\
\text { GYSVd-PR } \\
\end{array}$ & $\begin{array}{l}\text { TTGGATCCCACCTCGGAAGGCCGCC } \\
\text { TTGGATCCTAACCACAGGAACCACA } \\
\end{array}$ & 56 & $\begin{array}{l}\begin{array}{c}365-370 \\
(\mathrm{fl})\end{array} \\
\end{array}$ & $\begin{array}{l}\text { Jiang et al. } \\
2009 \text { a }\end{array}$ \\
\hline GYSVd-1 & $\begin{array}{l}\text { GYSVd-1-mF } \\
\text { GYSVd-1-mRl }\end{array}$ & $\begin{array}{l}\text { CAAAGCCCTTTTTCTTTCAACTGAG } \\
\text { CCCAGAGCAGCGTGGTCC }\end{array}$ & 52 & 249 & $\begin{array}{l}\text { Hajizadeh } \\
\text { et al. } 2012\end{array}$ \\
\hline GYSVd-2 & $\begin{array}{l}\mathrm{cl}- \\
\mathrm{h} 3+\end{array}$ & $\begin{array}{l}\text { ACCGGCTTCGGAGATAGAAG } \\
\text { AATGAGCCTCGTCGTCGA }\end{array}$ & 56 & 123 & $\begin{array}{l}\text { Wan Chow } \\
\text { Wah \& } \\
\text { Symons, } \\
1997\end{array}$ \\
\hline
\end{tabular}




\begin{tabular}{|c|c|c|c|c|c|}
\hline Viroid & Primer & Primer sequence (5'-3') & $\begin{array}{c}\mathrm{At} / \mathbf{T m} \\
\left({ }^{\circ} \mathbf{C}\right)^{*}\end{array}$ & $\begin{array}{l}\text { Fragment } \\
\text { length (nt) }\end{array}$ & Reference \\
\hline GYSVd-2 & $\begin{array}{l}\mathrm{c} 2- \\
\mathrm{hl+}\end{array}$ & $\begin{array}{l}\text { CCGAGGTGTAACCACAGGAACC } \\
\text { TTGAGGCCCGGCGAAACGC }\end{array}$ & 55 & 194 & $\begin{array}{l}\text { Wan Chow } \\
\text { Wah \& } \\
\text { Symons, } \\
1997 \\
\end{array}$ \\
\hline GYSVd-2 & $\begin{array}{l}\text { Fw } \\
\text { Rev }\end{array}$ & \begin{tabular}{|l|} 
TTGAGGCCCGGCGAAACGC \\
ACCGGCTTCGGAGATAGAAG \\
\end{tabular} & 60 & $363(\mathrm{fl})$ & $\begin{array}{l}\text { Eiras et al. } \\
2006\end{array}$ \\
\hline GYSVd-2 & $\begin{array}{l}\text { GYSVd-2-P1 } \\
\text { GYSVd-2-P2 }\end{array}$ & $\begin{array}{l}\text { ACTAGTACTTTCTTCTATCTCCGAAGC } \\
\text { ACTAGTCCGAGGACCTTTTCTAGCGCTC }\end{array}$ & 56 & $363(\mathrm{fl})$ & $\begin{array}{l}\text { Jiang et al. } \\
2009 \mathrm{c}\end{array}$ \\
\hline $\begin{array}{l}\text { GYSVd-3 } \\
\text { (=CGVd) }\end{array}$ & $\begin{array}{l}\text { GYSVd-PF } \\
\text { GYSVd-PR }\end{array}$ & \begin{tabular}{|l} 
TTGGATCCCACCTCGGAAGGCCGCC \\
TTGGATCCTAACCACAGGAACCACA \\
\end{tabular} & 56 & 366 (fl) & $\begin{array}{l}\text { Jiang et al. } \\
2009 \mathrm{a}\end{array}$ \\
\hline HSVd & $\begin{array}{l}\text { HV1M } \\
\text { HV2P }\end{array}$ & $\begin{array}{l}\text { GGCTCAAGAGAGGATCCGCG } \\
\text { CCTCTGGGGAATTCTCGAGTTGC }\end{array}$ & 65 & $\begin{array}{l}\text { 295-300 } \\
\text { (fl) }\end{array}$ & $\begin{array}{l}\text { Polivka et } \\
\text { al. } 1996\end{array}$ \\
\hline HSVd & $\begin{array}{l}\mathrm{F} \\
\mathrm{R} \\
\end{array}$ & $\begin{array}{l}\text { CTGGGGAATTCTCGAGTTGCC } \\
\text { AGGGGCTCAAGAGAGGATCCG } \\
\end{array}$ & 50 & 297 (fl) & $\begin{array}{l}\text { Farkas et } \\
\text { al. } 1999\end{array}$ \\
\hline HSVd & $\begin{array}{l}\text { HSV-83M } \\
\text { HSV-78P }\end{array}$ & \begin{tabular}{|l|} 
AACCCGGGGCTCCTTTCTCA \\
AACCCGGGGCAACTCTTCTC \\
\end{tabular} & $\begin{array}{l}50 \\
56\end{array}$ & $\sim 300$ (fl) & $\begin{array}{l}\text { Sano et al. } \\
2001\end{array}$ \\
\hline HSVd & $\begin{array}{l}\text { Fw } \\
\text { Rev }\end{array}$ & $\begin{array}{l}\text { ACTCTTCTCAGAATCCAGCGAG } \\
\text { TGCCCCGGGGCTCCTTTCTCAGGT }\end{array}$ & 60 & $\begin{array}{l}297-302 \\
\text { (fl) }\end{array}$ & $\begin{array}{l}\text { Eiras et al. } \\
2006\end{array}$ \\
\hline
\end{tabular}

$\mathrm{AGVd}=$ Australian grapevine viroid, $\mathrm{CEVd}=$ Citrus exocortis viroid, $\mathrm{CGVd}=$ Chinese grapevine viroid, HSVd $=$ Hop stunt viroid, GYSVd-1, -2 and $-3=$ Grapevine yellow speckle viroid-1, -2 and-3, and GHVd = Grapevine hammerhead viroid, nd = no data, $\mathrm{fl}=$ proper full length viroid could be amplified *published annealing temperatures

Table 2. Virus-specific primers

\begin{tabular}{|c|c|c|c|c|c|c|}
\hline Virus* & Primer name & Primer sequence (5'-3') & $\begin{array}{l}\mathrm{At} / \mathrm{Tm} \\
\left({ }^{\circ} \mathbf{C}\right) * *\end{array}$ & $\begin{array}{c}\text { Fragment } \\
\text { length } \\
\text { (nt) }\end{array}$ & Gene & Reference \\
\hline GFLV & $\begin{array}{l}\text { GFLV H2999 } \\
\text { GFLV C3310 } \\
\end{array}$ & $\begin{array}{l}\text { TCGGGTGAGACTGCGCAACTTCCTA } \\
\text { GATGGTAACGCTCCCGCTGCTCTT }\end{array}$ & 52 & 311 & RNA2-polyprotein & $\begin{array}{l}\text { MacKenzie et } \\
\text { al. } 1997\end{array}$ \\
\hline GFLV & $\begin{array}{l}\text { GFLVFw } \\
\text { GFLVRev }\end{array}$ & $\begin{array}{l}\text { ATGCTGGATATCGTGACCCTGT } \\
\text { GAAGGTATGCCTGCTTCAGTGG }\end{array}$ & 56 & 118 & RNA1-polyprotein & $\begin{array}{l}\text { Gambino \& } \\
\text { Gribaudo } \\
2006\end{array}$ \\
\hline GFLV & $\begin{array}{l}\text { F CPS } \\
\text { R EV00N1 } \\
\end{array}$ & $\begin{array}{l}\text { TTGTGCGCCCAGATCTCTCTTTACCA } \\
\text { GACTACACATATATACACTTGGGTCTTTTAA }\end{array}$ & 55 & 555 & RNA2-polyprotein & $\begin{array}{l}\text { Demangeat et } \\
\text { al. } 2004\end{array}$ \\
\hline GFLV & $\begin{array}{l}\text { GFLV V1/F } \\
\text { GFLV C1/R }\end{array}$ & $\begin{array}{l}\text { ACCGGATTGACGTGGGTGAT } \\
\text { CCAAAGT0TGGTTTCCCAAGA } \\
\end{array}$ & nd & 322 & RNA2-polyprotein & $\begin{array}{l}\text { Sanchez et al. } \\
1991\end{array}$ \\
\hline GFLV & $\begin{array}{l}\text { GFLVpoly5238FwGFLV } \\
\text { poly6048Rev }\end{array}$ & $\begin{array}{l}\text { ATCGATACTCCTGGTACG } \\
\text { ATAAAGCTCGACAAGTGC } \\
\end{array}$ & 52 & 828 & RNA1-polyprotein & $\begin{array}{l}\text { Pacifico et al. } \\
2011\end{array}$ \\
\hline GFLV & $\begin{array}{l}\text { GFLV CP 433V } \\
\text { GFLV CP 912C }\end{array}$ & $\begin{array}{l}\text { GAACTGGCAAGCTGTCGTAGAAC } \\
\text { GCTCATGTCTCTCTGACTTTGACC }\end{array}$ & 58 & 711 & RNA2-polyprotein & $\begin{array}{l}\text { Osman \& } \\
\text { Rowhani } \\
2006 \\
\end{array}$ \\
\hline GFLV & $\begin{array}{l}\text { GFLV-sp s } \\
\text { Nepo-A a } \\
\end{array}$ & $\begin{array}{l}\text { TCAGATTTTAAGGGCGTCCA } \\
\text { TGDCCASWVARYTCYCCATA }\end{array}$ & 50 & 260 & RNA2-polyprotein & $\begin{array}{l}\text { Digiaro et al. } \\
2007\end{array}$ \\
\hline ArMV & $\begin{array}{l}\text { ArMVFw } \\
\text { ArMVRev }\end{array}$ & $\begin{array}{l}\text { TGACAACATGGTATGAAGCACA } \\
\text { TATAGGGCCTTTCATCACGAAT }\end{array}$ & 56 & 402 & RNA1-polyprotein & $\begin{array}{l}\text { Gambino \& } \\
\text { Gribaudo } \\
2006 \\
\end{array}$ \\
\hline ArMV & $\begin{array}{l}\mathrm{H} 1124 \\
\mathrm{C} 1642 \\
\end{array}$ & \begin{tabular}{|l|} 
CAGCGGATTGGGAGTTCGT \\
TTGGCCCAGATATAGCGTAAAAAT \\
\end{tabular} & 50 & 517 & RNA2-polyprotein & $\begin{array}{l}\text { MacKenzie et } \\
\text { al. } 1997\end{array}$ \\
\hline ArMV & \begin{tabular}{|l|l|}
$\mathrm{H} 428$ \\
$\mathrm{C} 867$ \\
\end{tabular} & \begin{tabular}{|l|} 
GCGGCGGATTGGGAGTT \\
CGATGGTAGGGGGAGCGTATT \\
\end{tabular} & 54 & 440 & RNA2-polyprotein & $\begin{array}{l}\text { Nassuth et al. } \\
2000\end{array}$ \\
\hline ArMV & $\begin{array}{l}\text { ArMV-sp s } \\
\text { Nepo-A a } \\
\end{array}$ & \begin{tabular}{|l} 
GCGGGAATATATCTGAAA \\
TGDCCASWVARYTCYCCATA \\
\end{tabular} & 60 & 301 & RNA2-polyprotein & $\begin{array}{l}\text { Digiaro et al. } \\
2007\end{array}$ \\
\hline ArMV & \begin{tabular}{|l|} 
Upper \\
Lower \\
\end{tabular} & \begin{tabular}{|l|} 
CGGATTGGGAGTTCGTTGTCG \\
CCGTTCCATTCACTAACAACTC \\
\end{tabular} & 50 & 340 & RNA2-polyprotein & $\begin{array}{l}\text { Bertolini et al. } \\
2001\end{array}$ \\
\hline ArMV & $\begin{array}{l}\text { ArMV-CP1202F } \\
\text { ArMV CP1313R }\end{array}$ & $\begin{array}{l}\text { CTGTGCCATCCTTCCCCAATGAT } \\
\text { GAGATGCTCCATCCATGCCAGT }\end{array}$ & 58 & 294 & RNA2-polyprotein & $\begin{array}{l}\text { Osman \& } \\
\text { Rowhani } \\
2006 \\
\end{array}$ \\
\hline ToRSV & $\begin{array}{l}\text { TRSV-sp s } \\
\text { Nepo-A a } \\
\end{array}$ & $\begin{array}{l}\text { CAGTGAGGATGCACGCCCC } \\
\text { TGDCCASWVARYTCYCCATA } \\
\end{array}$ & 50 & 202 & RNA2-polyprotein & $\begin{array}{l}\text { Digiaro et al. } \\
2007\end{array}$ \\
\hline ToRSV & $\begin{array}{l}\text { ToRSV5(fw) } \\
\text { ToRSV6(rev) }\end{array}$ & $\begin{array}{l}\text { AGGTAGGACGCYATTGTTCCAGG } \\
\text { AGTCTCAACTTAACATACCACTAC }\end{array}$ & 54 & 428 & $\begin{array}{l}\text { RNA1-polyprotein } \\
\text { 3'UTR }\end{array}$ & Li et al. 2011 \\
\hline
\end{tabular}




\begin{tabular}{|c|c|c|c|c|c|c|}
\hline Virus* & Primer name & Primer sequence (5'-3') & $\begin{array}{l}\mathrm{At} / \mathrm{Tm} \\
\left({ }^{\circ} \mathrm{C}\right)^{* *}\end{array}$ & $\begin{array}{c}\text { Fragment } \\
\text { length } \\
\text { (nt) }\end{array}$ & Gene & Reference \\
\hline ToRSV & $\begin{array}{l}\text { ToRSV g-V/F } \\
\text { ToRSV g-C/R }\end{array}$ & $\begin{array}{l}\text { GTCACTACTCTTAACGCTAACC } \\
\text { CCACTCATACCTCCAGTCATC }\end{array}$ & 58 & 444 & RNA2-polyprotein & $\begin{array}{l}\text { Osman et al. } \\
2008\end{array}$ \\
\hline NepoA & $\begin{array}{l}\text { Nepo-A s } \\
\text { Nepo-A a } \\
\end{array}$ & $\begin{array}{l}\text { GGHDTBCAKTMYSARRARTGG } \\
\text { TGDCCASWVARYTCYCCATA }\end{array}$ & 50 & 256 & RNA2-polyprotein & $\begin{array}{l}\text { Digiaro et al. } \\
2007\end{array}$ \\
\hline GCMV & $\begin{array}{l}\text { GCMV 5'3140 } \\
\text { GCMV 3'3831 }\end{array}$ & $\begin{array}{l}\text { CATGGTCTAGCCACTAGGAG } \\
\text { GTAGTGGCACACATGATGGC }\end{array}$ & 54 & 692 & RNA2-polyprotein & $\begin{array}{l}\text { Brandt \& } \\
\text { Himmler } \\
1995 \\
\end{array}$ \\
\hline GCMV & $\begin{array}{l}\text { Nepo-B s } \\
\text { GCMV-sp-a }\end{array}$ & $\begin{array}{l}\text { ATGTGYGCHACYACWGGHATGCA } \\
\text { CTGCAAGGGAACTTGATAAGGG }\end{array}$ & 50 & 187 & RNA2-polyprotein & $\begin{array}{l}\text { Digiaro et al. } \\
2007\end{array}$ \\
\hline TBRV & $\begin{array}{l}\text { Nepo-B s } \\
\text { TBRV-sp-a }\end{array}$ & $\begin{array}{l}\text { ATGTGYGCHACYACWGGHATGCA } \\
\text { ATGACACTCTAGAAGAAAGTTG }\end{array}$ & 50 & 486 & RNA2-polyprotein & \begin{tabular}{|l} 
Digiaro et al. \\
2007
\end{tabular} \\
\hline NepoB & $\begin{array}{l}\text { Nepo-B s } \\
\text { Nepo_B a } \\
\end{array}$ & $\begin{array}{l}\text { ATGTGYGCHACYACWGGHATGCA } \\
\text { TTCTCTDHAAGAAATGCCTAAGA }\end{array}$ & 50 & 391 & RNA2-polyprotein & $\begin{array}{l}\text { Digiaro et al. } \\
2007\end{array}$ \\
\hline GBLV & $\begin{array}{l}\text { GBLV-CPs } \\
\text { GBLV-CPa }\end{array}$ & $\begin{array}{l}\text { AGTGCCCTTTTAGCCGATACCAG } \\
\text { TCACTTAAGTGGCGTTACGCT }\end{array}$ & 58 & 1565 & RNA2-polyprotein & $\begin{array}{l}\text { Elbeaino et al. } \\
2011\end{array}$ \\
\hline GLRaV-1 & $\begin{array}{l}\text { LR1CPF1 } \\
\text { LR1CPR1 }\end{array}$ & $\begin{array}{l}\text { CTAGCGTTATATCTCAAAATGA } \\
\text { CCCATCACTTCAGCACATAAA } \\
\end{array}$ & nd & 502 & coat protein & $\begin{array}{l}\text { Engel et al. } \\
2010\end{array}$ \\
\hline GLRaV-1 & $\begin{array}{l}\text { GLRaV-1Fw } \\
\text { GLRaV-1Rev }\end{array}$ & $\begin{array}{l}\text { TCTTTACCAACCCCGAGATGAA } \\
\text { GTGTCTGGTGACGTGCTAAACG }\end{array}$ & 56 & 232 & coat protein & $\begin{array}{l}\text { Gambino \& } \\
\text { Gribaudo } \\
2006 \\
\end{array}$ \\
\hline GLRaV-1 & $\begin{array}{l}\text { GLRaV1poly230Fw } \\
\text { GLRaV1poly1227Rev }\end{array}$ & $\begin{array}{l}\text { CCACGATAAGYGACAACTTCCCGA } \\
\text { CGTTAACTTGAGRTCGAACCCAA }\end{array}$ & 50 & 998 & $\begin{array}{l}\text { RNA dependent } \\
\text { RNA polymerase }\end{array}$ & $\begin{array}{l}\text { Pacifico et al. } \\
2011\end{array}$ \\
\hline GLRaV-1 & $\begin{array}{l}\text { HSP70-417 F } \\
\text { HSP70-737 R }\end{array}$ & $\begin{array}{l}\text { GAGCGACTTGCGACTTATCGA } \\
\text { GGTAAACGGGTGTTCTTCAATTCT }\end{array}$ & 58 & 320 & $\begin{array}{l}\text { HSP70-like } \\
\text { protein }\end{array}$ & $\begin{array}{l}\text { Osman et al. } \\
2007\end{array}$ \\
\hline GLRaV-1 & $\begin{array}{l}\text { LQV1-H47 } \\
\text { LEV1-C447 }\end{array}$ & $\begin{array}{l}\text { GTTACGGCCCTTTGTTTATTATGG } \\
\text { CGACCCCTTTATTGTTTGAGTATG }\end{array}$ & 60 & 401 & coat protein & $\begin{array}{l}\text { Osman \& } \\
\text { Rowhani, } \\
2006\end{array}$ \\
\hline GLRaV-1 & $\begin{array}{l}\text { LR1 HSP70-149 f } \\
\text { LR1 HSP70-293 r }\end{array}$ & $\begin{array}{l}\text { ACCTGGTTGAACGAGATCGCTT } \\
\text { GTAAACGGGTGTTCTTCAATTCTCT }\end{array}$ & 60 & 145 & $\begin{array}{l}\text { HSP70-like } \\
\text { protein }\end{array}$ & $\begin{array}{l}\text { Osman et al. } \\
2007\end{array}$ \\
\hline GLRaV-1 & $\begin{array}{l}\text { LR1-9727U } \\
\text { LR1-10019D } \\
\end{array}$ & $\begin{array}{l}\text { TCGTAACGGCCGCTTCAGTA } \\
\text { GTTCGTAACGTGCACGGAAG }\end{array}$ & 56 & 303 & & $\begin{array}{l}\text { Nakaune \& } \\
\text { Nakano } 2006 \\
\end{array}$ \\
\hline GLRaV-2 & $\begin{array}{l}\text { LR2 12474U } \\
\text { LR2 12806D }\end{array}$ & $\begin{array}{l}\text { TTGACAGCAGCCGATTAAGCG } \\
\text { CTGACATTATTGGTGCGACGG }\end{array}$ & 56 & 333 & $\begin{array}{l}\text { HSP90-like } \\
\text { protein }\end{array}$ & $\begin{array}{l}\text { Nakaune \& } \\
\text { Nakano } 2006\end{array}$ \\
\hline GLRaV-2 & $\begin{array}{l}\text { LR2 V2dCPf2 } \\
\text { LR2 V2CPr1 }\end{array}$ & $\begin{array}{l}\text { ACGGTGTGCTATAGTGCGTG } \\
\text { GCAGCTAAGTACGAATCTTC }\end{array}$ & nd & 514 & $\begin{array}{l}\text { minor and major } \\
\text { coat protein }\end{array}$ & $\begin{array}{l}\text { Bertazzon \& } \\
\text { Angelini } 2004 \\
\end{array}$ \\
\hline GLRaV-2 & $\begin{array}{l}\text { GLRaV-2F } \\
\text { GLRaV-2R }\end{array}$ & $\begin{array}{l}\text { GGTGATAACCGACGCCTCTA } \\
\text { CCTAGCTGACGCAGATTGCT }\end{array}$ & 56 & 543 & major coat protein & $\begin{array}{l}\text { Gambino \& } \\
\text { Gribaudo } \\
2006 \\
\end{array}$ \\
\hline GLRaV-2 & $\begin{array}{l}\text { LR2-U2 } \\
\text { LR2-L2 }\end{array}$ & $\begin{array}{l}\text { ATAATTCGGCGTACATCCCCACTT } \\
\text { GCCCTCCGCGCAACTAATGACAG }\end{array}$ & 52 & 331 & $\begin{array}{l}\text { HSP70-like } \\
\text { protein }\end{array}$ & $\begin{array}{l}\text { Bertazzon \& } \\
\text { Angelini } 2004\end{array}$ \\
\hline GLRaV-2 & $\begin{array}{l}\text { CPV F } \\
\text { CPC R }\end{array}$ & $\begin{array}{l}\text { TGGAGTTGATGTCCGACAGC } \\
\text { ACGACCGAACGTTCTAAGTT }\end{array}$ & 58 & 338 & major coat protein & $\begin{array}{l}\text { Osman et al. } \\
2007\end{array}$ \\
\hline GLRaV-2 & $\begin{array}{l}\text { RGHSP227V/F } \\
\text { RGHSP777C/R }\end{array}$ & $\begin{array}{l}\text { GCGACTCCAGCAACTTTAGTGA } \\
\text { GTCTAACGAAAGATCGGGTTCTAAG }\end{array}$ & 58 & 551 & $\begin{array}{l}\text { HSP70-like } \\
\text { protein }\end{array}$ & $\begin{array}{l}\text { Osman et al. } \\
2008\end{array}$ \\
\hline GLRaV-3 & $\begin{array}{l}\text { LR3 LC1F } \\
\text { LR3 LC2R }\end{array}$ & $\begin{array}{l}\text { CGCTAGGGCTGTGGAAGTATT } \\
\text { GTTGTCCCGGGTACCAGATAT }\end{array}$ & 52 & 546 & $\begin{array}{l}\text { HSP70-like } \\
\text { protein }\end{array}$ & $\begin{array}{l}\text { Turturo et al. } \\
2005\end{array}$ \\
\hline GLRaV-3 & $\begin{array}{l}\text { GLRaV-3F } \\
\text { GLRaV-3R }\end{array}$ & $\begin{array}{l}\text { TACGTTAAGGACGGGACACAGG } \\
\text { TGCGGCATTAATCTTCATTG }\end{array}$ & 56 & 336 & coat protein & $\begin{array}{l}\text { Gambino \& } \\
\text { Gribaudo } \\
2006 \\
\end{array}$ \\
\hline GLRaV-3 & $\begin{array}{l}\text { LR3-H330 } \\
\text { LR3-C629 }\end{array}$ & $\begin{array}{l}\text { GATGCTTTCGCGTATTTCTTG } \\
\text { CGGCACGATCGTACTTTCTAA }\end{array}$ & 54 & 300 & $\begin{array}{l}\text { HSP90-like } \\
\text { protein }\end{array}$ & $\begin{array}{l}\text { Mackenzie et } \\
\text { al. } 1997\end{array}$ \\
\hline
\end{tabular}




\begin{tabular}{|c|c|c|c|c|c|c|}
\hline Virus* & Primer name & Primer sequence (5'-3') & $\begin{array}{l}\text { At/Tm } \\
\left({ }^{\circ} \mathbf{C}\right)^{* * *}\end{array}$ & $\begin{array}{c}\text { Fragment } \\
\text { length } \\
\text { (nt) }\end{array}$ & Gene & Reference \\
\hline GLRaV-3 & $\begin{array}{l}\mathrm{CP}-111 \mathrm{~F} \\
\mathrm{CP}-722 \mathrm{R} \\
\end{array}$ & $\begin{array}{l}\text { AAAGTAGGTTAAGGACGGGACACA } \\
\text { AGGGTCGCCGTGATGAAG }\end{array}$ & 58 & 612 & coat protein & $\begin{array}{l}\text { Osman et al. } \\
2007\end{array}$ \\
\hline GLRaV-3 & $\begin{array}{l}\text { GLRaV3-56f } \\
\text { GLRaV3-285r }\end{array}$ & $\begin{array}{l}\text { AAGTGCTCTAGTTAAGGTCAGGAGTGA } \\
\text { GTATTGGACTACCTTTCGGGAAAAT }\end{array}$ & 60 & 230 & $\begin{array}{l}\text { HSP70-like } \\
\text { protein }\end{array}$ & $\begin{array}{l}\text { Bertolini et al. } \\
2010\end{array}$ \\
\hline GLRaV-3 & $\begin{array}{l}\text { GLRaV3poly7209Fw } \\
\text { GLRaV3poly8145Rev }\end{array}$ & $\begin{array}{l}\text { GGGTTGTGACGACTCTGTGGCGCAT } \\
\text { GATATCTGAAGTTTTGGAAGCT }\end{array}$ & 52 & 958 & $\begin{array}{l}\text { RNA-dependent } \\
\text { RNA polymerase }\end{array}$ & $\begin{array}{l}\text { Pacifico et al. } \\
2011\end{array}$ \\
\hline GLRaV-3 & $\begin{array}{l}\text { LR3-8033U } \\
\text { LR3-8408D }\end{array}$ & $\begin{array}{l}\text { TTACGGCACAAACGCTACCAG } \\
\text { CTGGTGTGGTAGAGTAGTTCC }\end{array}$ & 56 & 376 & $\begin{array}{l}\text { HSP90-like } \\
\text { protein }\end{array}$ & $\begin{array}{l}\text { Nakaune \& } \\
\text { Nakano } 2006\end{array}$ \\
\hline GLRaV-3 & $\begin{array}{l}\text { H587(Fw) } \\
\text { C547 (Rev) } \\
\end{array}$ & \begin{tabular}{|l} 
ATAAGCATTCGGGATGGACC \\
ATTAACTTGACGGATGGCACGC
\end{tabular} & 62 & 340 & $\begin{array}{l}\text { RNA-dependent } \\
\text { RNA polymerase }\end{array}$ & \begin{tabular}{|l} 
Minafra \& \\
Hadidi 1994 \\
\end{tabular} \\
\hline GLRaV4 & $\begin{array}{l}\text { LR4 HSPV-F } \\
\text { LR4 HSPV-R }\end{array}$ & $\begin{array}{l}\text { ACATTCTCCACCTTGTGCTTTT } \\
\text { CATACAAGCGAGTGCAATTACA }\end{array}$ & 58 & 321 & $\begin{array}{l}\text { HSP70-like } \\
\text { protein }\end{array}$ & $\begin{array}{l}\text { Osman et al. } \\
2007\end{array}$ \\
\hline GLRaV5 & $\begin{array}{l}\text { HPPV F } \\
\text { HSPV R }\end{array}$ & $\begin{array}{l}\text { AACACTCTGCTTTTCTGCTGGCA } \\
\text { TCTCCAGAAGACGGACCAATGTAA }\end{array}$ & 58 & 273 & $\begin{array}{l}\text { HSP70-like } \\
\text { protein }\end{array}$ & $\begin{array}{l}\text { Osman \& } \\
\text { Rowhani } \\
2006 \\
\end{array}$ \\
\hline GLRaV5 & $\begin{array}{l}\text { HSP70-29F } \\
\text { HSP70-634R }\end{array}$ & $\begin{array}{l}\text { CACTCTGCTTTTCTGCTGGCA } \\
\text { CGACGCACAGACGTAGGATGA }\end{array}$ & 58 & 600 & $\begin{array}{l}\text { HSP70-like } \\
\text { protein }\end{array}$ & $\begin{array}{l}\text { Osman et al. } \\
2007\end{array}$ \\
\hline GLRaV4-5 & $\begin{array}{l}\text { HSP45A } \\
\text { HSP45B }\end{array}$ & $\begin{array}{l}\text { GTATCTYATGTACCAACAGAT } \\
\text { GGTATGAACAARTTCAATGC }\end{array}$ & 53 & 370 & $\begin{array}{l}\text { HSP70-like } \\
\text { protein }\end{array}$ & $\begin{array}{l}\text { Routh et al. } \\
1998\end{array}$ \\
\hline GLRaV7 & $\begin{array}{l}\text { LR7F } \\
\text { LR7R }\end{array}$ & $\begin{array}{l}\text { TATATCCCAACGGAGATGGC } \\
\text { ATGTTCCTCCACCAAAATCG }\end{array}$ & nd & 502 & $\begin{array}{l}\text { HSP70-like } \\
\text { protein }\end{array}$ & $\begin{array}{l}\text { Engel et al. } \\
2008\end{array}$ \\
\hline GLRaV9 & $\begin{array}{l}\text { LR9F } \\
\text { LR9R }\end{array}$ & $\begin{array}{l}\text { CGGCATAAGAAAAGATGGCAC } \\
\text { TCATTCACCACTGCTTGAAC }\end{array}$ & 58 & 393 & $\begin{array}{l}\text { HSP70-like } \\
\text { protein }\end{array}$ & $\begin{array}{l}\text { Alkowni et al. } \\
2004\end{array}$ \\
\hline GVA & $\begin{array}{l}\text { GVA Fw } \\
\text { GVA Rev }\end{array}$ & $\begin{array}{l}\text { GAGGTAGATATAGTAGGACCTA } \\
\text { TCGAACATAACCTGTGGCTC }\end{array}$ & 56 & 272 & coat protein & $\begin{array}{l}\text { Gambino \& } \\
\text { Gribaudo } \\
2006\end{array}$ \\
\hline GVA & $\begin{array}{l}\text { GVA 6540U } \\
\text { GVA 6880D } \\
\end{array}$ & \begin{tabular}{|l|} 
TTTGGGTACATCGCGTTGGT \\
TCTAAGCCCGACGCGAAGT \\
\end{tabular} & 56 & 341 & coat protein & \begin{tabular}{|l|} 
Nakaune \& \\
Nakano 2006 \\
\end{tabular} \\
\hline GVA & $\begin{array}{l}\text { GVAH587 V1/F } \\
\text { GVAC995 C1/R } \\
\end{array}$ & $\begin{array}{l}\text { GACAAATGGCACACTACG } \\
\text { AAGCCTGACCTAGTCATCTTGG }\end{array}$ & 62 & 430 & coat protein & \begin{tabular}{|l|} 
Minafra \& \\
Hadidi 1994 \\
\end{tabular} \\
\hline GVA & $\begin{array}{l}\text { GVADeg7Fw } \\
\text { GVADeg4Rev }\end{array}$ & $\begin{array}{l}\text { MRNCCMGARTAYGATGC } \\
\text { TRTARAABGCYACCTC } \\
\end{array}$ & 52 & 652 & replicase & $\begin{array}{l}\text { Pacifico et al. } \\
2011\end{array}$ \\
\hline GVA & $\begin{array}{l}\text { GVA-H7038 } \\
\text { GVA-C7273 }\end{array}$ & $\begin{array}{l}\text { AGGTCCACGTTTGCTAAG } \\
\text { CATCGTCTGAGGTTTCTACTAT }\end{array}$ & 54 & 240 & $\begin{array}{l}\text { putative RNA } \\
\text { binding protein }\end{array}$ & $\begin{array}{l}\text { MacKenzie } \\
1997 \\
\end{array}$ \\
\hline GVB & $\begin{array}{l}\text { GVB H28 } \\
\text { GVB C410 } \\
\end{array}$ & $\begin{array}{l}\text { GTGCTAAGAACGTCTTCACAGC } \\
\text { ATCAGCAAACACGCTTGAACCG }\end{array}$ & 56 & 460 & $\begin{array}{l}\text { putative RNA } \\
\text { binding protein }\end{array}$ & \begin{tabular}{|l} 
Minafra \& \\
Hadidi 1994 \\
\end{tabular} \\
\hline GVD & \begin{tabular}{|l|} 
GVDORF2-F1 \\
GVDORF2-R1 \\
\end{tabular} & \begin{tabular}{|l} 
TAATAGGGCCTAAGTC \\
GGGCGTTGAATACACCTTTAGC \\
\end{tabular} & 50 & 371 & coat protein & \begin{tabular}{|l|} 
Lebas \& \\
Ward 2012 \\
\end{tabular} \\
\hline GVD & $\begin{array}{l}\text { D_ORF/F } \\
\text { D_ORF/R }\end{array}$ & $\begin{array}{l}\text { CTTAGGACGCTCTTCGGGTACA } \\
\text { CTGCTCTCCAACCGACGACT }\end{array}$ & 58 & 465 & coat protein & $\begin{array}{l}\text { Abou- } \\
\text { Ghanem et al. } \\
1997\end{array}$ \\
\hline GVD & $\begin{array}{l}\text { GVDmu-554f } \\
\text { GVDmu-661r }\end{array}$ & $\begin{array}{l}\text { AGGTGTATTCAACGCCCAGTC } \\
\text { GCCCTACGCTTCTTAGCATAACTAC }\end{array}$ & 57 & 108 & $\begin{array}{l}\text { coat protein and } \\
\text { RNA binding } \\
\text { protein }\end{array}$ & $\begin{array}{l}\text { Osman et al. } \\
2013\end{array}$ \\
\hline $\begin{array}{l}\text { GVA, GVB, } \\
\text { GVD }\end{array}$ & $\begin{array}{l}\text { VT-165 F1 } \\
\text { VT-594 R1 }\end{array}$ & $\begin{array}{l}\text { ACYCTCTTYGGGTACATHGC } \\
\text { GCBCCYTCHGTVCGAAAGAG }\end{array}$ & 55 & 429 & coat protein & $\begin{array}{l}\text { Osman et al. } \\
2013\end{array}$ \\
\hline GVE & $\begin{array}{l}\text { GVE-1For } \\
\text { GVERev }\end{array}$ & $\begin{array}{l}\text { AATGGAGTCAAAAGCGATCC } \\
\text { GTAGGGTCAATCAACCAACA }\end{array}$ & 55 & 992 & coat protein & $\begin{array}{l}\text { Coetzee et al. } \\
2010\end{array}$ \\
\hline GFkV & $\begin{array}{l}\text { GFkVF } \\
\text { GFkVR }\end{array}$ & $\begin{array}{l}\text { TGACCAGCCTGCTGTCTCTA } \\
\text { TGGACAGGGAGGTGTAGGAG }\end{array}$ & 56 & 179 & coat protein & $\begin{array}{l}\text { Gambino \& } \\
\text { Gribaudo } \\
2006\end{array}$ \\
\hline
\end{tabular}




\begin{tabular}{|c|c|c|c|c|c|c|}
\hline Virus* & Primer name & Primer sequence (5'-3') & $\begin{array}{l}\mathrm{At} / \mathrm{Tm} \\
\left({ }^{\circ} \mathrm{C}\right)^{* *}\end{array}$ & \begin{tabular}{|c|} 
Fragment \\
length \\
(nt)
\end{tabular} & Gene & Reference \\
\hline GFkV & $\begin{array}{l}\mathrm{RD} 1 \\
\mathrm{RD} 2\end{array}$ & $\begin{array}{l}\text { CYCARCAYAARGTVAACGA } \\
\text { GCGCATGCABGTSAGRGGG }\end{array}$ & 56 & 386 & replicase & $\begin{array}{l}\text { Nakaune \& } \\
\text { Nakano } 2006\end{array}$ \\
\hline GFkV & $\begin{array}{l}\text { GFk V1/F } \\
\text { GFk C1/R }\end{array}$ & $\begin{array}{l}\text { GGTCCTCGGCCCAGTGAAAAAGTA } \\
\text { GGCCAGGTTGTAGTCGGTGTTGTC }\end{array}$ & 58 & 352 & replicase & $\begin{array}{l}\text { Osman et al. } \\
2008\end{array}$ \\
\hline GFkV & $\begin{array}{l}\text { FL CP V } \\
\text { FL CP C }\end{array}$ & $\begin{array}{l}\text { CCTCGTGTAAGCATCCATCT } \\
\text { CCGAAGACGGAGAGGATCTC }\end{array}$ & 58 & 260 & coat protein & $\begin{array}{l}\text { Osman \& } \\
\text { Rowhani, } \\
2006\end{array}$ \\
\hline GFkV & $\begin{array}{l}\text { GFkV OB F } \\
\text { GFkV OB R }\end{array}$ & $\begin{array}{l}\text { CGAGAACTCTCTTTTCACCTC } \\
\text { CCGGCGTGGATGTAGAG }\end{array}$ & 60 & 147 & replicase & $\begin{array}{l}\text { Bertolini et al. } \\
2010\end{array}$ \\
\hline GFkV & $\begin{array}{l}\text { GFkVrep4944Fw } \\
\text { GFkC1m/R }\end{array}$ & $\begin{array}{l}\text { GCGYATCCTYGACRGCCG } \\
\text { GCCAGGYTGTAGTCGGTGTTGT }\end{array}$ & 52 & 324 & replicase & $\begin{array}{l}\text { Pacifico et al. } \\
2011\end{array}$ \\
\hline GRSPaV & $\begin{array}{l}\text { RSP-up1 } \\
\text { RSP-do2 }\end{array}$ & $\begin{array}{l}\text { TGAGATGGTYGCTAATATCG } \\
\text { CTATTAGTACGGTATTCCAG }\end{array}$ & 56 & 242 & $\begin{array}{l}\text { coat protein + } \\
\text { 3’UTR }\end{array}$ & $\begin{array}{l}\text { Nakaune \& } \\
\text { Nakano } 2006\end{array}$ \\
\hline GRSPaV & $\begin{array}{l}\text { RSPaVFw } \\
\text { RSPaVRev }\end{array}$ & $\begin{array}{l}\text { GGGTGGGATGTAGTAACTTTTGA } \\
\text { GCAAGTGAAATGAAAGCATCACT }\end{array}$ & 56 & 155 & replicase & $\begin{array}{l}\text { Gambino \& } \\
\text { Gribaudo } \\
2006\end{array}$ \\
\hline GRSPaV & $\begin{array}{l}48 \mathrm{~V} \\
49 \mathrm{C} \\
\end{array}$ & $\begin{array}{l}\text { AGCTGGGATTATAAGGGAGGT } \\
\text { CCAGCCGTTCCACCACTAAT }\end{array}$ & 52 & 330 & coat protein & $\begin{array}{l}\text { Lima et al. } \\
2006\end{array}$ \\
\hline GRSPaV & $\begin{array}{l}\text { RSP-H5638 } \\
\text { RSP-C5992 } \\
\end{array}$ & $\begin{array}{l}\text { AGGGATTGGCTGTTAGATGTT } \\
\text { CTTCAGGCAACCCCAAAAA }\end{array}$ & 54 & 355 & replicase & $\begin{array}{l}\text { MacKenzie, } \\
1997\end{array}$ \\
\hline GPGV & $\begin{array}{l}\text { GPgV5619f } \\
\text { GPgV6668r }\end{array}$ & $\begin{array}{l}\text { TGGGAGGATTGCAACAGGGGCT } \\
\text { ATTCGCCTCGCTCAACTTTGCGA }\end{array}$ & nd & 1049 & movement protein & $\begin{array}{l}\text { Giampetruzzi } \\
\text { et al. } 2012\end{array}$ \\
\hline GPGV & $\begin{array}{l}\text { GPGVFw } \\
\text { GPGVRev }\end{array}$ & $\begin{array}{l}\text { ATGTCGATTCGTCAGGAGCTG } \\
\text { CTACATACTAAATGCACTC } \\
\end{array}$ & nd & 588 & coat protein & $\begin{array}{l}\text { Cho et al. } \\
2013\end{array}$ \\
\hline GPGV & $\begin{array}{l}\text { GPG-5637F } \\
\text { GPG5939R }\end{array}$ & $\begin{array}{l}\text { ATTGCGGAGTTGCCTTCAAAG } \\
\text { CTGAGAAGCATTGTCCCA }\end{array}$ & 56 & 303 & movement protein & $\begin{array}{l}\text { Glasa et al. } \\
2014\end{array}$ \\
\hline GPGV & $\begin{array}{l}\text { GPG6609F } \\
\text { GPG7020R } \\
\end{array}$ & $\begin{array}{l}\text { GAGATCAACAGTCAGGAGAG } \\
\text { GACTTCTGGTGCCTTATCAC }\end{array}$ & 56 & 412 & coat protein & $\begin{array}{l}\text { Glasa et al. } \\
2014\end{array}$ \\
\hline GRVFV & $\begin{array}{l}\text { GVFVC105F1 } \\
\text { GVFVC105R2 }\end{array}$ & $\begin{array}{l}\text { CCTGTCGCTTCCTTCTCATCT } \\
\text { CATCTTCCATGCCCATTTCTTG }\end{array}$ & nd & 323 & polyprotein1 & $\begin{array}{l}\text { Al Rwahnih } \\
\text { et al. } 2009\end{array}$ \\
\hline GSyV-1 & $\begin{array}{l}\text { Det-F } \\
\text { Det-R }\end{array}$ & $\begin{array}{l}\text { CAAGCCATCCGTGCATCTGG } \\
\text { GCCGATTTGGAACCCGATGG }\end{array}$ & nd & 296 & $\begin{array}{l}\text { putative movement } \\
\text { protein }\end{array}$ & $\begin{array}{l}\text { Al Rwahnih } \\
\text { et al. } 2009\end{array}$ \\
\hline GAMaV & $\begin{array}{l}\text { GAMaVF3 } \\
\text { GAMaVR2 }\end{array}$ & $\begin{array}{l}\text { GCATCTCCAATCTGTCCCAT } \\
\text { AGTACGAGGTCTCGGTGGTG }\end{array}$ & nd & 479 & $\begin{array}{l}\text { replicase- } \\
\text { associated } \\
\text { polyprotein }\end{array}$ & $\begin{array}{l}\text { Al Rwahnih } \\
\text { et al. } 2009\end{array}$ \\
\hline GVCV $^{\#}$ & $\begin{array}{l}\text { GVCV-F1 } \\
\text { GVCV-R1 }\end{array}$ & $\begin{array}{l}\text { CACGTTTCAAAGAAAGATGGAC } \\
\text { ATCCKTCCATGCAWCCGTCAG }\end{array}$ & 52 & 526 & $\begin{array}{l}\text { polyprotein } \\
\text { ORF3 }\end{array}$ & $\begin{array}{l}\text { Zhang et al. } \\
2011\end{array}$ \\
\hline GRBaV $^{\#}$ & $\begin{array}{l}\text { GRBaVF1 } \\
\text { GRBaVR1 }\end{array}$ & $\begin{array}{l}\text { CTCGTCGCATTTGTAAGA } \\
\text { ACTGACAAGGCCTACTACG }\end{array}$ & 60 & 557 & $\mathrm{~V} 2$ protein & $\begin{array}{l}\text { Al Rwahnih } \\
\text { et al. } 2013\end{array}$ \\
\hline
\end{tabular}

*ArMV: Arabis mosaic virus, GAMaV: Grapevine asteroid mosaic-associated virus, GBLV: Grapevine Bulgarian latent virus, GCMV: Grapevine chrome mosaic virus, GFLV: Grapevine fanleaf virus, GFkV: Grapevine fleck virus, GLRaV-1, -2, -3, -4, -5, -7 and -9: Grapevine leafroll-associated virus-1, -2, $-3,-4,-5,-7$ and -9 , respectively, GPGV: Grapevine pinot gris virus, GRBaV: Grapevine red blotch-associated virus, GRSPaV: Grapevine rupestris stem pitting-associated virus, GRVFV Grapevine rupestris vein-feathering virus, GSyV-1: Grapevine Syrah virus-1, GVCV: Grapevine vein clearing virus, GVA: Grapevine virus A, GVB: Grapevine virus B, GVD: Grapevine virus D, GVE: Grapevine virus E, Nepo A: Nepovirus subgroup A, Nepo B: Nepovirus subgroup B, TBRV: Tomato black ring virus, ToRSV: Tomato ringspot virus

**published annealing temperatures, $\mathrm{nd}=$ no data

\#: GRBaV and GVCV are DNA viruses.

Table 3. Phytoplasma specific primers

\begin{tabular}{|c|c|c|c|c|c|c|}
\hline Phytoplasma & Primer & Primer sequence (5'-3') & $\begin{array}{l}\text { At/Tm } \\
\left({ }^{\circ} \mathbf{C}\right)^{*}\end{array}$ & $\begin{array}{c}\text { Frag- } \\
\text { ment } \\
\text { length } \\
\text { (nt) }\end{array}$ & Target gene & Reference \\
\hline Universal & $\begin{array}{l}\text { P1 } \\
\text { P7 }\end{array}$ & $\begin{array}{l}\text { AAGAGTTTGATCCTGGCTCAGGATT } \\
\text { CGTCCTTCATCGGCTCTT }\end{array}$ & 50 & 1850 & $\begin{array}{l}16 \mathrm{~S} \text { and intergenic } \\
16 \mathrm{~S}-23 \mathrm{~S} \text { and a small } \\
\text { part of } 23 \mathrm{~S} \text { rRNA } \\
\text { gene }\end{array}$ & $\begin{array}{l}\text { Deng and Hiruki 1991, } \\
\text { Schneider et al. } 1995\end{array}$ \\
\hline Universal & $\begin{array}{l}\text { fU5 } \\
\text { rU3 }\end{array}$ & $\begin{array}{l}\text { CGGCAATGGAGGAAACT } \\
\text { TTCAGCTACTCTTTGTAACA }\end{array}$ & 55 & 880 & 16S rRNA gene & Lorenz et al., 1995 \\
\hline
\end{tabular}




\begin{tabular}{|c|c|c|c|c|c|c|}
\hline Phytoplasma & Primer & Primer sequence (5'-3') & $\begin{array}{c}\mathrm{At} / \mathrm{Tm} \\
\left({ }^{\circ} \mathbf{C}\right)^{*}\end{array}$ & $\begin{array}{c}\text { Frag- } \\
\text { ment } \\
\text { length } \\
\text { (nt) }\end{array}$ & Target gene & Reference \\
\hline Universal & \begin{tabular}{|l|} 
R16F2n \\
R16R2 \\
\end{tabular} & $\begin{array}{l}\text { GAAACGACTGCTAAGACTGG } \\
\text { TGACGGGCGGTGTGTACAAACCCCG }\end{array}$ & 55 & 1250 & 16S rRNA gene & Lee et al., 1998 \\
\hline $\begin{array}{l}\text { Flavescence } \\
\text { dorée }(\mathrm{FD}) \\
(16 \mathrm{SrV}-\mathrm{C}, \mathrm{D})\end{array}$ & $\begin{array}{l}\text { FD9f1 } \\
\text { FD9r1 }\end{array}$ & $\begin{array}{l}\text { GAATTAGAACTGTTTGAAGACG } \\
\text { TTTGCTTTCATATCTTGTATCG }\end{array}$ & 55 & 1300 & Non ribosomal DNA & $\begin{array}{l}\text { OEEP/EPPO } 2007^{* *} \text {, } \\
\text { Daire et al., } 1997\end{array}$ \\
\hline $\begin{array}{l}\text { Flavescence } \\
\text { dorée } \\
(16 S r V-C, D)\end{array}$ & $\begin{array}{l}\text { FD9f3b } \\
\text { FD9r2 }\end{array}$ & $\begin{array}{l}\text { TAATAAGGTAGTTTTATATGACAAG } \\
\text { GACTAGTCCCGCCAAAAG }\end{array}$ & 55 & 1150 & Non ribosomal DNA & $\begin{array}{l}\text { OEEP/EPPO 2007**, } \\
\text { Clair et al., 2003a, } \\
\text { 2003b, } \\
\text { Angelini et al., } 2001\end{array}$ \\
\hline $\begin{array}{l}\text { Bois noir (BN, } \\
\text { Stolbur) } \\
(16 \text { SrXII-A) }\end{array}$ & $\begin{array}{l}\text { STOL11f2 } \\
\text { STOL11r1 }\end{array}$ & $\begin{array}{l}\text { TATTTTCCTAAAATTGATTGGC } \\
\text { TGTTTTTGCACCGTTAAAGC }\end{array}$ & 55 & 830 & Non ribosomal DNA & $\begin{array}{l}\text { OEEP/EPPO 2007**, } \\
\text { Daire et al., 1997, } \\
\text { Clair et al. 2003a, } \\
\text { 2003b }\end{array}$ \\
\hline Bois noir & $\begin{array}{l}\text { STOL11f3 } \\
\text { STOL11r2 }\end{array}$ & $\begin{array}{l}\text { ACGAGTTTTGATTATGTTCAC } \\
\text { GATGAATGATAACTTCAACTG }\end{array}$ & 55 & 720 & Non ribosomal DNA & $\begin{array}{l}\text { OEEP/EPPO } 2007^{* *} \text {, } \\
\text { Clair et al. } 2003 \mathrm{~b}\end{array}$ \\
\hline $\begin{array}{l}16 \mathrm{~S} \text { group } \\
\text { I,II,XII,XV } \\
\text { specific } \\
\end{array}$ & $\begin{array}{l}\text { R16(I)F1 } \\
\text { R16(I)R1 }\end{array}$ & $\begin{array}{l}\text { TAAAAGACCTAGCAATAGG } \\
\text { CAATCCGAACTAAGACTCT }\end{array}$ & 50 & 1100 & 16S rRNA gene & Lee et al., 1994 \\
\hline $\begin{array}{l}16 \mathrm{~S} \text { group III } \\
\text { specific }\end{array}$ & $\begin{array}{l}\text { R16(III)F1 } \\
\text { R16(III)R1 }\end{array}$ & $\begin{array}{l}\text { AAGAGTGGAAAAACTCCC } \\
\text { TTCGAACTGAGATTGA }\end{array}$ & 50 & 800 & 16S rRNA gene & Lee et al., 1994 \\
\hline $\begin{array}{l}16 \mathrm{~S} \text { group } \mathrm{V} \\
\text { specific }\end{array}$ & $\begin{array}{l}\text { R16(V)F1 } \\
\text { R16(V)R1 }\end{array}$ & $\begin{array}{l}\text { TTAAAAGACCTTCTTCGG } \\
\text { TTCAATCCGTACTGAGACTACC }\end{array}$ & 50 & 1100 & 16S rRNA gene & Lee et al., 1994 \\
\hline
\end{tabular}

*published annealing temperatures, **see also papers cited therein

Table 4. Bacterium specific primers

\begin{tabular}{|c|c|c|c|c|c|c|}
\hline Species & Primer & Primer sequence $\left(5^{\prime}-3^{\prime}\right)$ & $\mathrm{At} / \mathrm{Tm}\left({ }^{\circ} \mathbf{C}\right) *$ & $\begin{array}{l}\text { Fragment } \\
\text { length (nt) }\end{array}$ & Target gene & Reference \\
\hline Agrobacterium spp. & $\begin{array}{l}\text { UF f (fw) } \\
\text { B1R r (rev) } \\
\text { B2R r (rev) } \\
\text { AvR r (rev) } \\
\text { ArR r (rev) }\end{array}$ & $\begin{array}{l}\text { GTAAGAAGCGAACGCAGGGAACT } \\
\text { GACAATGACTGTTCTACGCGTAA } \\
\text { TCCGATACCTCCAGGGCCCCTCACA } \\
\text { AACTAACTCAATCGCGCTATTAAC } \\
\text { AAAACAGCCACTACGACTGTCTT }\end{array}$ & 67 & $\begin{array}{l}184 \\
1066 \\
478 \\
1006\end{array}$ & 23S RNA gene & $\begin{array}{l}\text { Puławska et al. } \\
2006\end{array}$ \\
\hline $\begin{array}{l}\text { Agrobacterium } \\
\text { tumefaciens }\end{array}$ & $\begin{array}{l}\text { VCF (fw) } \\
\operatorname{VCR}(\text { rev) }\end{array}$ & $\begin{array}{l}\text { ATCATTTGTAGCGACT } \\
\text { AGCTCAAACCTGCTTC }\end{array}$ & 55 & 730 & $\operatorname{vir} C$ gene & $\begin{array}{l}\text { Sawada et al. } \\
1995\end{array}$ \\
\hline A. tumefaciens & $\begin{array}{l}\operatorname{virD} 2 \mathrm{~A}(\mathrm{fw}) \\
\operatorname{virD} 2 \mathrm{C}(\mathrm{rev}) \\
\operatorname{virD} 2 \mathrm{E}(\mathrm{rev}) \\
\end{array}$ & $\begin{array}{l}\text { ATGCCCGATCGAGCTCAAGT } \\
\text { TCGTCTGGCTGACTTTCGTCATAA } \\
\text { CCTGACCCAAACATCTCGGCTGCCCA }\end{array}$ & 50 & 224,338 & virD2 gene & $\begin{array}{l}\text { Haas et al. } \\
1995\end{array}$ \\
\hline Agrobacterium spp. & $\begin{array}{l}\text { VCF3 (fw) } \\
\text { VCR3 (rev) }\end{array}$ & $\begin{array}{l}\text { GGCGGGCGYGCYGAAAGRAARACYT } \\
\text { AAGAACGYGGNATGTTGCATCTYAC }\end{array}$ & 60 & 414 & $\operatorname{virC1-virC2}$ & $\begin{array}{l}\text { Kawaguchi et } \\
\text { al. } 2005\end{array}$ \\
\hline Agrobacterium vitis & $\begin{array}{l}\text { PGF (fw) } \\
\text { PGR (rev) }\end{array}$ & $\begin{array}{l}\text { GGGGCAGGATGCGTTTTTGAG } \\
\text { GACGGCACTGGGGCTAAGGAT }\end{array}$ & $54-58$ & 466 & $\begin{array}{l}\text { poligalacturo- } \\
\text { nase gene }\end{array}$ & $\begin{array}{l}\text { Szegedi \& } \\
\text { Bottka } 2002 \\
\end{array}$ \\
\hline A.vitis & $\begin{array}{l}\text { Ab3-F3 (fw) } \\
\text { Ab3-R4(rev) }\end{array}$ & $\begin{array}{l}\text { ATGACGGTAGTCGGAGAAGAAGCC } \\
\text { CTGTCTCTGTGTCCCCGAAAGG }\end{array}$ & 62 & 570 & $\begin{array}{l}\text { 16S rDNA } \\
\text { gene }\end{array}$ & $\begin{array}{l}\text { Kawaguchi et } \\
\text { al. } 2005\end{array}$ \\
\hline $\begin{array}{l}\text { A. tumefaciens, } \\
\text { A. vitis }\end{array}$ & $\begin{array}{l}\text { iaaH-F10 (fw) } \\
\text { iaaH-R10 (rev) }\end{array}$ & $\begin{array}{l}\text { GGAAACATGCATGAGTTATCGTT } \\
\text { CCACATCAGCATCAAGGTCATC }\end{array}$ & 54 & 424 & $\begin{array}{l}\text { oct, nop pTi- } \\
\text { iaaH }\end{array}$ & $\begin{array}{l}\text { Bini et al. } \\
2008\end{array}$ \\
\hline A. vitis & $\begin{array}{l}\text { S4iaaM5 (fw), } \\
\text { S4iaaM3 (rev) }\end{array}$ & $\begin{array}{l}\text { CGCGTCCCCGTTTACACTA } \\
\text { CGAGATCGCGCTTCAAGAT } \\
\end{array}$ & 54 & 800 & $\begin{array}{l}\text { vitopin pTi } \\
\text { iaaM }\end{array}$ & $\begin{array}{l}\text { Bini et al. } \\
2008\end{array}$ \\
\hline $\begin{array}{l}\text { Xylophilus } \\
\text { ampelinus }\end{array}$ & $\begin{array}{l}\text { S3 (fw) } \\
\text { S4 (rev) }\end{array}$ & $\begin{array}{l}\text { GGTGTTAGGCCGAGTAGTGAG } \\
\text { GGTCTTTCACCTGACGCGTTA }\end{array}$ & 55 & 277 & ITS & $\begin{array}{l}\text { Botha et al. } \\
2001\end{array}$ \\
\hline X. ampelinus & $\begin{array}{l}\text { Xamp1.27A (fw) } \\
\text { Xamp1.27B(REV) }\end{array}$ & $\begin{array}{l}\text { GATCGCAAGAAATCCCGATG } \\
\text { AAATTCCCTTCGTTGTTCTG }\end{array}$ & 60 & 310 & $\mathrm{nd}^{* *}$ & $\begin{array}{l}\text { Manceau et al. } \\
2000\end{array}$ \\
\hline Xylella fastidiosa & $\begin{array}{l}\text { RST31(fw), } \\
\text { RST33 (rev) }\end{array}$ & $\begin{array}{l}\text { GCGTTAATTTTCGAAGTGATTCGATTGC } \\
\text { CACCATTCGTATCCCGGTG }\end{array}$ & 55 & 733 & $\begin{array}{l}\text { Specific EcoRI } \\
\text { fragment }\end{array}$ & $\begin{array}{l}\text { OEEP/EPPO } \\
2004\end{array}$ \\
\hline
\end{tabular}




\begin{tabular}{|c|c|c|c|c|c|c|}
\hline Species & Primer & Primer sequence (5'-3') & $\mathbf{A t} / \operatorname{Tm}\left({ }^{\circ} \mathbf{C}\right)^{*}$ & $\begin{array}{l}\text { Fragment } \\
\text { length (nt) }\end{array}$ & Target gene & Reference \\
\hline X. fastidiosa & $\begin{array}{l}\text { S19 (fw) } \\
\text { S21 (fw) } \\
\text { A19 (rew) } \\
\text { A21 (rew) } \\
\end{array}$ & $\begin{array}{l}\text { CGGCAGCACATTGGTAGTA } \\
\text { GCAAATTGGCACTCAGTATCG } \\
\text { CTCCTCGCGGTTAAGCTAC } \\
\text { CGATACTGAGTGCCAATTTGC }\end{array}$ & 55 & $600-1350$ & $16 S r D N A$ & $\begin{array}{l}\text { Rodrigues et } \\
\text { al. } 2003\end{array}$ \\
\hline$X$. fastidiosa & $\begin{array}{l}\text { FXYgyr499 (fw) } \\
\text { RXYgyr907 (rev) } \\
\end{array}$ & $\begin{array}{l}\text { CAGTTAGGGGTGTCAGCG } \\
\text { CTCAATGTAATTACCCAAGGT }\end{array}$ & 54 & 429 & gyrase b & $\begin{array}{l}\text { Rodrigues et } \\
\text { al. } 2003\end{array}$ \\
\hline
\end{tabular}

*published annealing temperatures, **nd: no data

Table 5. Fungus specific primers

\begin{tabular}{|c|c|c|c|c|c|c|}
\hline Species & Primer & Primer sequence (5'-3') & At $/ \mathbf{T m}\left({ }^{\circ} \mathbf{C}\right)^{*}$ & $\begin{array}{l}\text { Fragment } \\
\text { length (nt) }\end{array}$ & Target gene & Reference \\
\hline Universal & $\begin{array}{l}\text { ITS1F(fw) } \\
\text { ITS5 (fw), } \\
\text { ITS4(rev) }\end{array}$ & $\begin{array}{l}\text { CTTGGTCATTTAGAGGAAGTAA } \\
\text { GGAAGTAAAAGTCGTAACAAGG } \\
\text { TCCTCCGCTTATTGATATGC }\end{array}$ & $\begin{array}{l}55 \\
50\end{array}$ & $\begin{array}{l}584 \\
620\end{array}$ & $\begin{array}{l}\text { ITS } \\
(5.8 S-28 S \\
\text { rDNA) }\end{array}$ & $\begin{array}{l}\text { Hamelin et al. } \\
1996 \\
\text { Tegli et al. } \\
2000\end{array}$ \\
\hline $\begin{array}{l}\text { Phaeomoniella } \\
\text { chlamydospora }\end{array}$ & $\begin{array}{l}\text { MONO1475 (fw) } \\
\text { MONO1962 } \\
\text { (rev) }\end{array}$ & $\begin{array}{l}\text { GATCAAACGCCTTGGTGGTCC } \\
\text { ATTGCATCTTGCAAAGGGAC }\end{array}$ & 52 & 489 & SCAR & $\begin{array}{l}\text { Rigdway et al. } \\
2005\end{array}$ \\
\hline $\begin{array}{l}\text { Phaeoacremonium } \\
\text { chlamydosporum } \\
(P c h)\end{array}$ & $\begin{array}{l}\text { Pal1N(fw), } \\
\text { Pal2 (rev) }\end{array}$ & $\begin{array}{l}\text { AGGTCGGGGGCCAAC } \\
\text { AGGTGTAAACTACTGCGC }\end{array}$ & 50 & 400 & ITS & $\begin{array}{l}\text { Tegli et al. } \\
2000\end{array}$ \\
\hline $\begin{array}{l}\text { Phaeoacremonium } \\
\text { aleophilum (Pal) }\end{array}$ & $\begin{array}{l}\text { Pch1 (fw), } \\
\text { Pch2 (rev) }\end{array}$ & $\begin{array}{l}\text { CTCCAACCCTTTGTTTATC } \\
\text { TGAAAGTTGATATGGACCC }\end{array}$ & 50 & 360 & ITS & $\begin{array}{l}\text { Tegli et al. } \\
2000\end{array}$ \\
\hline $\begin{array}{l}\text { Phaeoacremonium } \\
\text { spp. }\end{array}$ & $\begin{array}{l}\text { Pm1 (fw) } \\
\text { Pm2 (rev) }\end{array}$ & $\begin{array}{l}\text { CTCCAAACCCTTTGTGAACAT } \\
\text { CGAGCCCGCCACTGACTT }\end{array}$ & 52 & 415 & ITS & $\begin{array}{l}\text { Aroca \& } \\
\text { Raposo } 2007\end{array}$ \\
\hline Botryosphaeria spp. & $\begin{array}{l}\text { ITS1 } \\
\text { NL4 }\end{array}$ & $\begin{array}{l}\text { TCCGTAGGTGAACCTGCGG } \\
\text { GGTCCGTGTTTCAAGACGG }\end{array}$ & 50 & 1200 & $\begin{array}{l}\text { ITS and rDNA } \\
\text { regions }\end{array}$ & $\begin{array}{l}\text { Alves et al. } \\
2005\end{array}$ \\
\hline $\begin{array}{l}\text { Cylindrocarpon } \\
\text { destructans }\end{array}$ & $\begin{array}{l}\text { Dest1(fw) Dest } 4 \\
(\mathrm{rev})\end{array}$ & $\begin{array}{l}\text { TTGTTGCCTCGGCGGTGCCTG } \\
\text { GGTTTAACGGCGTGGCCGCGCTGTT }\end{array}$ & 60 & 400 & ITS1-ITS2 & $\begin{array}{l}\text { Hamelin et al. } \\
1996 \\
\text { Nascimento et } \\
\text { al. } 2001\end{array}$ \\
\hline Rosellinia necatrix & $\begin{array}{l}\text { R1(fw) } \\
\text { R2(fw) } \\
\text { R3(fw) } \\
\text { R5(fw) } \\
\text { R10(fw), and } \\
\text { R7(rev) } \\
\text { R8(rev) } \\
\text { R11(rev) }\end{array}$ & $\begin{array}{l}\text { ATAACTCCCAAAACCCATGTGA } \\
\text { CAAAACCCATGTGAACATACCA } \\
\text { CGAAGTGCCCTACCCTGTTA } \\
\text { CACGAAACTCTGTTTAGCATTGA } \\
\text { CCCCTGTTGCTTAGTGTTGG } \\
\text { AACCATAGGCGAGATGAGAAAT } \\
\text { CCGAGGTCAACCTTTGGTATAG } \\
\text { CACAACCATAGGCGAGATGA }\end{array}$ & 60 & $112-500$ & ITS1-ITS2 & $\begin{array}{l}\text { Schena et al. } \\
2002\end{array}$ \\
\hline $\begin{array}{l}\text { Roesleria } \\
\text { subterranea }\end{array}$ & $\begin{array}{l}\text { Rs1R(fw) } \\
\text { Rs2F(rev) }\end{array}$ & $\begin{array}{l}\text { TCCGGAACGTCTATAGCGAGGAGA } \\
\text { TCGCGGGCAACCGGCTCACGC }\end{array}$ & 60 & 360 & ITS1-ITS2 & $\begin{array}{l}\text { Neuhauser et } \\
\text { al. } 2009\end{array}$ \\
\hline
\end{tabular}

*published annealing temperatures

\section{Acknowledgements}

This work was supported by the Hungarian Ministry of Agriculture/Rural Development and the KTIA_AIK_12 -12013-0001 project. N. Czotter participates in the Program for Reinforcement of Scientists of Hungarian Ministry of Agriculture. We apologize to those authors who were not cited due to space limit.

\section{References}

Abolmaaty A, Vu C, Oliver J \& Levin, RE (2000): Development of a new lysis solution for releasing genomic DNA from bacterial cells for DNA amplification by polymerase chain reaction. Microbios. 101: 181-189.
Abou-Ghanem N, Saldarelli P, Minafra A, Buzkan N, Castellano MA \& Martelli GP (1997): Properties of Grapevine virus D, a novel putative Trichovirus. Journal of Plant Pathology. 78:15-25.

Alkowni R, Rowhani A, Daubert S \& Golino D (2004): Partial characterization of a new ampelovirus associated with grapevine leafroll disease. Journal of Plant Pathology. 86: 123-133.

Al Rwahnih M, Daubert S, Golino D \& Rowhani A (2009): Deep sequencing analysis of RNAs from a grapevine showing Syrah decline symptoms reveals a multiple virus infection that includes a novel virus. Virology. 387: 395-401.

Al Rwahnih M, Dave A, Anderson MM, Rowhani A, Uyemoto JK \& Sudarshana MR (2013): Association of a DNA virus with grapevines affected by Red Blotch Disease in California. Phytopathology. 103: 1069-1076. 
Alves A., Phillips AJL, Henriques I \& Correia A (2005): Evaluation of amplified ribosomal DNA restriction analysis as a method for the identification of Botryosphaeria species. FEMS Microbiology Letters. 245: 221-229.

Angelini E (2010): Field assessment and diagnostic methods for detection of grapevine phytoplasmas. [In: S. Delrot $\mathrm{S}$ et al., eds., Methodologies and results in grapevine research.] Springer Science+Business Media BV, 247-258.

Angelini E, Clair D, Borgo M, Bertaccini A \& Boudon-Padieu E (2001): Flavescence dorée in France and Italy - Occurrence of closely related phytoplasma isolates and their near relationships to Palatinate grapevine yellows and an alder phytoplasma. Vitis. 40: 79-86.

Aroca A \& Raposo R (2007): PCR-based strategy to detect and identify species of Phaeoacremonium causing grapevine diseases. Applied and Environmental Microbiology. 73: 2911-2918.

Bertazzon N \& Angelini E (2004): Advances in the detection of Grapevine leafroll-associated virus 2 variants. Journal of Plant Pathology. 86: 283-290.

Bertolini E, Olmos A, Martinez MC, Gorris MT \& Cambra M (2001): Single-step multiplex RT-PCR for simultaneous and colourimetric detection of six RNA viruses in olive trees. Journal of Virological Methods. 96: 33-41.

Bertolini E, Garcia J, Yuste A \& Olmos A (2010): High prevalence of viruses in table grape from Spain detected by real-time RT-PCR. European Journal of Plant Pathology. 128: 283-287.

Bini F, Kuczmog A, Putnoky P, Otten L, Bazzi C, Burr TJ \& Szegedi E (2008): Novel pathogen-specific primers for the detection of Agrobacterium vitis and Agrobacterium tumefaciens. Vitis. 47: 181-189.

Bisztray GyD, Civerolo EL, Dula T, Kölber M, Lázár J, Mugnai L, Szegedi E \& Savka M A (2012): Grapevine pathogens spreading with propagating plant stock: detection and methods for elimination. [In: Szabó PV \& Shojania J, eds, Grapevines: Varieties, Cultivation and Management,] Nova Science Publishers, Inc., 1-86.

Botha WJ, Serfonstein S, Greyling MM \& Berger DK (2001): Detection of Xylophilus ampelinus in grapevine cuttings using a nested polymerase chain reaction. Plant Pathology. 50: 515-526.

Brandt S \& Himmler G (1995): Detection of nepoviruses in ligneous grapevine material by using IC/PCR. Vitis. 34: 127-128.

Cho IS, Jung SM, Cho JD, Choi GS \& Lim HS (2013): First report of grapevine 'Pinot gris' virus infecting grapevine in Korea. New Disease Reports. 27: 10.

Clair D, Larrue J, Aubert G, Gillet J, Cloquemin G \& BoudonPadieu E (2003a): Direct sensitive diagnosis of Flavescence dorée and Bois noir using a multiplex nested-PCR assay and its use in field surveys, 82-83. 14th ICVG Conference, Locorotondo, 12-17th September.

Clair D, Larrue J, Aubert G, Gillet J, Cloquemin G \& BoudonPadieu E (2003b): A multiplex nested-PCR assay for sensitive and simultaneous detection and direct identification of phytoplasma in the Elm yellows group and Stolbur group and its use in survey of grapevine yellows in France. Vitis. 42: 151-157.

Coetzee B, Maree HJ, Stephan D, Freeborough MJ \& Burger JT (2010): The first complete nucleotide sequence of a grapevine virus E variant. Archives of Virology. 155: 1357-1360.

Cseh E (2012): Occurrence of grapevine viruses in Hungary and molecular studies of some Hungarian Grapevine leafroll-associated virus 1 and 3 isolates. Pannon University, Georgikon Faculty, Keszthely (Hungary), http://konyvtar.uni-pannon.hu/doktori/2013/
Cseh_Eszter_dissertation.pdf (in Hungarian with English summary). $\mathrm{PhD}$ thesis.

Constable FE, Nicholas P \& Brendan CR (2010): Development and validation of diagnostic protocols for the detection of endemic and exotic pathogens of grapevines. Final Report DPI 05/04, http:// www.gwrdc.com.au.

Contaldo N, Bertaccini A, Paltrinieri S, Windsor HM \& Windsor GD (2012): Axenic culture of plant pathogenic phytoplasmas. Phytopathologica Mediterranea. 51: 607-617.

Daire X, Clair D, Reinert W \& Boudon-Padieu E (1997): Detection and differentiation of grapevine yellows phytoplasmas belonging to the elm yellows group and to the stolbur subgroup by PCR amplification of non-ribosomal DNA. European Journal of Plant Pathology. 103: 507-514.

Demangeat G, Komar V, Cornuet P, Esmenjaud D \& Fuchs M (2004): Sensitive and reliable detection of grapevine fanleaf virus in a single Xiphinema index nematode vector. Journal of Virological Methods. 122: 79-86.

Deng S \& Hiruki C (1991): Localisation of pathogenic mycoplasmalike organisms in plant tissue using in situ hybridization. Proceedings of Japan Academy, Series B., Physical and Biological Sciences. 67: 197-202.

Digiaro M, Elbeaino T \& Martelli GP (2007): Development of degenerate and species-specific primers for the differential and simultaneous RT-PCR detection of grapevine-infecting nepoviruses of subgroups A, B and C. Journal of Virological Methods. 141: 34-40.

Dreo T, Gruden K, Manceau C, Janse JD \& Ravnikar M (2007): Development of a real-time PCR-based method for detection of Xylophilus ampelinus. Plant Pathology. 56: 9-16.

Eiras M, Targon MLPN, Fajardo TVM, Flores R \& Kitajima EW (2006): Citrus exocortis viroid and Hop Stunt viroid doubly infecting grapevines in Brasil. Phytopathologia Brasileira. 31: 440-446.

Elbeaino T, Digiaro M, Fallanaj F, Kuzmanovic S \& Martelli GP (2011): Complete nucleotide sequence and genome organisation of grapevine Bulgarian latent virus. Archives of Virology. 156: 875879.

Engel EA, Escobar P, Montt C, Gomez-Talquenca S \& Valenzuela PDT (2008): First report on the occurrence of Grapevine leafrollassociated virus 7 and 9 in Chilean grapevines. Plant Disease. 92: 1252-1253.

Engel EA, Escobar PF, Rojas LA, Rivera PA, Fiore N \& Valenzuela PDT (2010): A diagnostic oligonucleotide microarray for simultaneous detection of grapevine viruses. Journal of Virological Methods. 163: 445-451.

Fahrentrapp J, Michl G \& Breuer M (2013): Quantitative PCR assay for detection of Bois noir phytoplasmas in grape and insect tissue. Vitis. 52: 85-89.

Farkas E, Palkovics L, Mikulás J \& Balázs E (1999): High incidence of Hop Stunt viroid in Hungarian grapevines. Acta Phytopathologica et Entomologica Hungarica. 34: 7-11.

Franke KE, Liu Y \& Adams DO (1995): Yield and quality of RNA from grape beries at different developmental stages. American Journal of Enology and Viticulture. 46: 315-318.

Gambino G \& Gribaudo I (2006): Simultaneous detection of nine grapevine viruses by multiplex reverse transcription-polymerase chain reaction with coamplification of a plant RNA as internal control. Phytopathology. 96: 1223-1229.

Gambino G, Bondaz J \& Gribaudo I (2006): Detection and elimination of viruses in callus, somatic embryos and regenerated 
plantlets of grapevine. European Journal of Plant Pathology. 114: 397-404.

Gambino G, Perrone I \& Gribaudo I (2008): A rapid and effective method for RNA extraction from different tissues of grapevine and other woody plants. Phytochemical Analysis. 19: 520-525.

Giampetruzzi A, Roumi V, Roberto R, Malossini U, Yoshikawa N, La Notte P, Telizzi F, Credi R \& Saldarelli P (2012): A new grapevine virus discovered by deep sequencing of virus and viroid derived small RNAs in cv. 'Pinot gris'. Virus Research. 163: 262-268.

Ghignone S \& Migheli Q (2005): The database of PCR primers for phytopathogenic fungi. European Journal of Plant Pathology. 113: 107-109.

Glasa M, Predajna L, Kominek P, Nagyova A, Candresse T \& Olmos A (2014): Molecular characterization of divergent grapevine Pinot gris virus isolates and their detection in Slovak and Czech grapevines. Archives of Virology.

Grund E, Darissa O \& Adam G (2010): Application of FTA cards to sample microbial plant pathogens for PCR and RT-PCR. Journal of Phytopathology. 158: 750-757.

Guo R, Sano T, Cheng Z \& Li SF (2007): Detection of Australian grapevine viroid in a grapevine more than 100 years old in Xinjiang, China. Plant Pathology. 56: 339-339.

Haas JH, Moore LW, Ream W \& Manulis S (1995): Universal PCR primers for detection of phytopathogenic Agrobacterium strains. Applied and Environmental Microbiology. 61: 2879-2884.

Hajizadeh M, Navarro B, Bashir NS, Torchetti EM \& Di Serio F (2012): Development and validation of a multiplex RT-PCR method for the simultaneous detection of five grapevine viroids. Journal of Virological Methods. 179: 62-69.

Hamelin RC, Bérubé P, Gignac M \& Bourassa M (1996): Identification of root rot fungi in nursery seedlings by nested multiplex PCR. Applied and Environmental Microbiology. 62: 4026-4031.

Harper SJ, Ward LI \& Clover GRG (2010): Development of LAMP and real-time PCR methods for the rapid detection of Xylella fastidiosa for quarantine and field applications. Phytopathology. 100: 1282-1288.

Harper SJ, Delmiglio C, Ward LI \& Clover GRG (2011): Detection of Tomato black ring virus by real-time one-step RTPCR. Journal of Virological Methods. 171: 190-194.

Jiang D, Guo R, Wu Z, Wang H \& Li S (2009a): Molecular characterization of a member of a new species of grapevine viroid. Archives of Virology. 154: 1563-1566.

Jiang D, Peng S, Wu Z, Cheng Z \& Li S (2009b): Genetic diversity and phylogenetic analysis of Australian Grapevine Viroid $(\mathrm{AGVd})$ isolated from different grapevines in China. Virus Genes. 38: 178-183.

Jiang D, Zhang Z, Wu Z, Guo R, Wang H, Fan P \& Li S (2009c): Molecular characterization of grapevine yellow speckle viroid-2 (GYSVd-2). Virus Genes. 38: 515-520.

Jiang D, Sano T, Tsuji M, Araki H, Sagawa K, Purushothama CRA, Zhang Z, Guo R, Xie L, Wu Z, Wang H \& Li S (2012): Comprehensive diversity analysis of viroids infecting grapevine in China and Japan. Virus Research. 169: 237-245.

Johnson KL, Zheng D, Kaewnum S, Reid CL \& Burr TJ (2013): Development of a magnetic capture hybridization realtime PCR assay for detection of tumorigenic Agrobacterium vitis in grapevines. Phytopathology. 103: 633-640.
Kawaguchi A, Sawada H, Inoue K \& Nasu H (2005): Multiplex PCR for the identification of Agrobacterium biovar 3 strains. Journal of General Plant Pathology. 71: 54-59.

Lebas B \& Ward L (2012): Vitis (grapevine) post-entry quarantine testing manual. http://www.biosecurity.govt.nz/regs/imports/plants/ high-value-crops

Lee I-M, Gundersen DE, Hammond RW \& Davis RE (1994): Use of mycoplasmalike organism (MLO) group-specific oligonucleotide primers for nested-PCR assays to detect mixed-MLO infections in a single host plant. Phytopathology. 84: 559-566.

Lee I-M, Gundersen-Rindal DE, Davis RE \& Bartoszyk IM (1998): Revised classification scheme of phytoplasmas based an RFLP analyses of 16S rRNA and ribosomal protein gene sequences. International Journal of Systematic Bacteriology. 48: 1153-1169.

Li R, Mock R, Fuchs M, Halbrendt J, Howell B \& Liu Z (2011): Characterization of the partial RNA1 and RNA2 3'untranslated region of Tomato ringspot virus isolates from North America. Canadian Journal of Plant Pathology. 33: 94-99.

Li R, Mock R, Huang Q, Abad J, Hartung J \& Kinard G (2008): A reliable and inexpensive method of nucleic acid extraction for the PCR-based detection of diverse plant pathogens. Journal of Virological Methods. 154: 48-55.

Lima MF, Alkowni R, Uyemoto JK, Golino D, Osman F \& Rowhani A (2006): Molecular analysis of a California strain of Rupestris stem pitting-associated virus isolated from declining Syrah grapevines. Archives of Virology. 151: 1889-1894.

Lodhi MA, Ye G-N, Weeden NF \& Reisch BI (1994): A simple and efficient method for DNA extraction from grapevine cultivars and Vitis species. Plant Molecular Biology Reporter. 12: 6-13.

Lorenz KH, Schneider B, Ahrens U \& Seemüller E (1995): Detection of the apple proliferation and pear decline phytoplasmas by PCR amplification of ribosomal and nonribosomal DNA. Phytopathology. 85: 771-776.

MacKenzie DJ (1997): A standard protocol for the detection of viruses and viroids using a reverse transcription-polymerase chain reaction technique. Document CPHBT-RT-PCR 1.000 The Canadian Food Inspection Agency.

MacKenzie DJ, McLean MA, Murkerji S \& Green M (1997): Improved RNA extraction from woody plants for the detection of viral pathogens by reverse transcription polymerase chain reaction. Plant Disease. 81: 222-226.

Manceau C, Coutaud M-G \& Guyon R (2000): Assessment of subtractive hybridization to select species and subspecies specific DNA fragments for the identification of Xylophilus ampelinus by polymerase chain reaction (PCR). European Journal of Plant Pathology. 106: 243-253.

Martelli GP (2014): Directory of virus and virus-like diseases of the grapevine and their agents. Journal of Plant Pathology. (Rivista di Patologia Vegetale) Vol. 96, No 1 sup.

Martin MT, Cobos R, Martin L \& López-Enriquez L (2012): Real-time PCR Detection of Phaeomoniella chlamydospora and Phaeoacremonium aleophilum. Applied and Environmental Microbiology,. 78: 3985-3991.

Martinelli L, Candioli E, Costa D \& Minafra A (2002): Stable insertion and expression of the movement protein gene of Grapevine Virus A (GVA) in grape (Vitis rupestris S.). Vitis. 41: 189-193.

Minafra A \& Hadidi A (1994): Sensitive detection of grapevine virus A, B, or leafroll associated III from viruliferous mealybugs 
and infected tissue by cDNA amplification. Journal of Virological Methods. 47: 175-188.

Nakaune R \& Nakano M (2006): Efficient methods for sample processing and cDNA synthesis by RT-PCR for the detection of grapevine viruses and viroids. Journal of Virological Methods. 134: 244-249.

Nascimento T, Rego C \& Oliveira H (2001): Detection of Cylindrocarpon black-foot pathogens in grapevine by nested PCR. Phytopathologia Mediterranea. 40: S357-S361.

Nassuth A, Pollari E, Helmeczy K, Stewart S \& Köfalvi SA (2000): Improved RNA extraction and one-tube RT-PCR assay for simultaneous detection of control plant RNA plus several viruses in plant extracts. Journal of Virological Methods. 90: 37-49.

Neuhauser S, Huber L \& Kirscmair M (2009): A DNA based method to detect the grapevine root-rotting fungus Roesleria subterranea in soil and root samples. Phytopathologia Mediterranea. 48: 59-72.

OEEP/EPPO (2004): Diagnostic protocols for regulated pests: Xylella fastidiosa. OEEP/EPPO Bulletin. 34: 155-157.

OEEP/EPPO (2007): Grapevine flavescence dorée phytoplasma. OEEP/EPPO Bulletin. 37: 536-542.

Osman F \& Rowhani A (2006): Application of a spotting sample preparation technique for the detection of pathogens in woody plants by RT-PCR and real-time PCR (TaqMan). Journal of Virological Methods. 133: 130-136.

Osman F \& Rowhani A (2008): Real-time RT-PCR (TaqMan®) assays for the detection of viruses associated with Rugose wood complex of grapevine. Journal of Virological Methods. 154: 69-75.

Osman F, Leutenegger C, Golino D \& Rowhani A (2007): Realtime RT-PCR (TaqMan) assays for the detection of Grapevine Leafroll associated viruses 1-5 and 9. Journal of Virological Methods. 141: 22-29.

Osman F, Leutenegger C, Golino D \& Rowhani A (2008): Comparison of low-density arrays, RT-PCR and real-time TaqMan RT-PCR in detection of grapevine viruses. Journal of Virological Methods. 149: 292-299.

Osman F, Hodzic E, Omanska-Klusek A, Olineka T \& Rowhani A (2013): Development and validation of a multiplex quantitative PCR assay for the rapid detection of Grapevine virus A, B and D. Journal of Virological Methods. 194: 138-145.

Pacifico D, Caciagli P, Palmano S, Mannini F \& Marzachì C (2011): Quantitation of Grapevine leafroll associated virus-1 and -3, Grapevine virus A, Grapevine fanleaf virus and Grapevine fleck virus in field-collected Vitis vinifera L. 'Nebbiolo' by real-time time reverse transcription-PCR. Journal of Virological Methods. 171: 190-194.

Pacifico D, Caciagli P, Palmano S, Mannini F \& Marzachi C (2011): Quantitation of Grapevine leafroll associated virus-1 and -3 , Grapevine virus A, Grapevine fanleaf virus and Grapevine fleck virus in field-collected Vitis vinifera L. ,Nebbiolo' by realtime reverse transcription-PCR. Journal of Virological Methods. 172: 1-7.

Palacio-Bielsa A, Cambra MA \& López MM (2009): PCR detection and identification of plant-pathogenic bacteria: updated review of protocols (1989-2007). Journal of Plant Pathology. 91: 249-297.

Papayiannis LC (2014): Diagnostic real-time RT-PCR for the simultaneous detection of Citrus exocortis viroid and Hop stunt viroid. Journal of Virological Methods. 196: 93-99.
Pelletier C, Salar P, Gillet J, Cloquemin G, Vry P, Foissac X \& Malembic-Maher S (2009): Triplex real-time PCR assay for sensitive and simultaneous detection of phytoplasmas of the $16 \mathrm{SrV}$ and 16SrXII-A groups with an endogenous analytical control. Vitis. 48: 87-95.

Polivka H, Staub U \& Gross HJ (1996): Variation of viroid profiles in individual grapevine plants:novel grapevine yellow speckle viroid-1 mutants show alteration of hairpin I. Journal of General Virology. 77: 155-161.

Puławska J, Willems A \& Sobiczewski P (2006): Rapid and specific identification of four Agrobacterium species and bivars using multiplex PCR. Systematic and Applied Microbiology. 29: 470-479.

Ragozzino E, Faggioli F \& Barba M (2004): Development of a one-tube one-step RT-PCR protocol for the detection of seven viroids in four genera: Apscaviroid, Hostuviroid, Pelamoviroid and Pospiviroid. Journal of Virological Methods. 121: 25-29.

Rezaian M A, Krake LR \& Golino DA (1992): Common identity of grapevine viroids from USA and Australia revealed by PCR analysis. Intervirology. 34: 38-43.

Ridgway HJ, Steyaert JM, Pottinger BM, Carpenter M, Nicol D \& Stewart A (2005): Development of an isolate-specific marker for tracking Phaeomoniella chlamydospora infection in grapevines. Mycologia. 97: 1093-1101.

Rodrigues JLM, Silva-Stenico ME, Gomes JE, Lopes RS \& Tsai SM (2003): Detection and diversity assessment of Xylella fastidiosa in field-collected plant and insect samples by using 16S RNA and gyrB sequences. Applied and Environmental Microbiology. 69: 4249-4255.

Routh, G., Zhang, Y. P., Saldarelli, P. \& Rowhani, A. (1998): Use of degenerate primers for partial sequencing and RT-PCRbased assays of grapevine leafroll-associated viruses 4 and 5 . Phytopathology. 88: 1238-1243.

Sanchez F, Chay C, Borja MJ, Rowhani A, Romero J, Bruening G \& Ponz F (1991): cDNA sequence of the capsid protein gene and 3 ' untranslated region of a fanleaf isolate of grapevine fanleaf virus. Nucleic Acids Research. 19: 5440.

Sano T, Mimura R \& Ohsima K (2001): Phylogenic analysis of hop and grapevine isolates of Hop Stunt Viroid supports a grapevine origin for hop stunt disease. Virus Genes. 22: 53-59.

Sawada H, Ieki H \& Matsuda I (1995): PCR detection of Ti and Ri plasmids from phytopathogenic Agrobacterium strains. Applied and Environmental Microbiology. 61: 828-831.

Schena L, Nigro F \& Ippolito A (2002): Identification and detection of Rosellinia necatrix by conventional and real-time Scorpion-PCR. European Journal of Plant Pathology. 108: 355-366.

Schena L, Nigro F \& Ippolito A (2004): Real-time PCR detection and quantification of soilborne fungal pathogens: the case of Rosellinia necatrix, Phytophtora nicotianae, P. citrophthora, and Verticillium dahliae. Phytopathologia Mediterranea. 43: 273-280.

Schneider B \& Seemüller E (1996): Sequence and RFLP analysis of the gene coding for the elongation factor TU of several phytoplasma strains for differentiation and classification of phytoplasmas. IOM Letters. 4: 281.

Steenkamp J, Wiid I, Lourens A \& van Helden P (1994): Improved method for DNA extraction from Vitis vinifera. American Journal of Enology and Viticulture. 45: 102-106

Sun N, Deng C, Zhao X, Zhou Q, Ge G, LiuY, YanW \& Xia $Q$ (2014): Extraction of total nucleic acid based on silica-coated 
magnetic particles for RT-qPCR detection of plant RNA virus/ viroid. Journal of Virological Methods. 196: 204-211.

Szegedi E (2003): Opines in naturally infected grapevine crown gall tumors. Vitis. 42: 39-41.

Szegedi E \& Bottka S (2002): Detection of Agrobacterium vitis by polymerase chain reaction in grapevine bleeding sap after isolation on a semiselective medium. Vitis. 41: 37-42.

Tegli S, Bertelli E \& Surico G (2000): Sequence analysis of ITS ribosomal DNA in five Phaeoacremonium species and development of a PCR-based assay for the detection of $P$. chlamydosporum and P. aleophilum in grapevine tissue. Phytopathologia Mediterranea. 39: 134-149.

Thompson JR, Fuchs M, McLane H, Celebi-Toprak F, Fischer KF, Potte JL \& Perry KL (2014): Profiling viral infections in grapevine using a randomly primed reverse transcription-polymerase chain reaction/macroarray multiplex platform. Phytopathology. 104: 211-219.

Turturo C, Saldarelli P, Yafeng D, Digiaro M, Minafra A, Savino V \& Martelli GP (2005): Genetic variability and population structure of Grapevine leafroll-associated virus 3 isolates. Journal of General Virology. 86: 217-224.
Vasanthaiah HKN, Katam R \& Sheikh MB (2008): Efficient protocol for isolation of functional RNA from different grape tissue rich in polyphenols and polysaccharides for gene expression studies. Electronic Journal of Biotechnology. 11: 1-8.

Wan Chou Wah YF \& Symons RH (1997): A high sensitivity RT-PCR assay for the diagnosis of grapevine viroids in field and tissue culture samples. Journal of Virological Methods. 63: 57-69.

Wu Q, Wang Y, Cao M, Pantaleo V, Burgyán J, Li W-X \& Ding S-W (2012): Homology-independent discovery of replicating pathogenic circular RNAs by deep sequencing and a new computational algorithm. Proceedings of National Academy of Scienses of the United States of America. 109: 3938-3943.

Zhang Z, Peng S, Jiang D, Pan S, Wang H \& Li S (2012): Development of a polyprobe for simultaneous detection of four grapevine viroids in grapevine plants. European Journal of Plant Pathology. 132: 9-16.

Zhang Y, Singh K, Kaur R \& Qiu W (2011): Association of a novel DNA virus with the grapevine vein-clearing and vine decline syndrome. Phytopathology. 101: 1081-1090. 